\title{
A Qualitative Study on Experiences and Needs of Language Sample Analysis by Speech-Language Pathologists: Focused on Patients with Acquired Neurogenic Language Disorders
}

\author{
Ji Hye Yoon ${ }^{\mathrm{a}}$, So Jung $\mathrm{Oh}^{\mathrm{b}}$, YoonKyoung Lee ${ }^{\mathrm{a}}$ \\ ${ }^{a}$ Division of Speech Pathology and Audiology, Hallym University, Chuncheon, Korea \\ ${ }^{b}$ Department of Communication Disorders \& Audiology, Tongmyong University, Busan, Korea
}

Correspondence: YoonKyoung Lee, $\mathrm{PhD}$ Division of Speech Pathology and Audiology, College of Natural Sciences, Hallym University, 1 Hallymdaehak-gil, Chuncheon 24252, Korea Tel: +82332482219

Fax: +82332563420

E-mail: ylee@hallym.ac.kr

Received: April 20, 2020

Revised: May 11, 2020

Accepted: May 19, 2020

This work was supported by the Ministry of Education of the Republic of Korea and the National Research Foundation of Korea (NRF2019S1A5A2A03052093).

This research was supported by Hallym University Research Fund in 2020 (No. HRF-202003-009)
Objectives: The purpose of this study is to examine the opinions of the language sample analysis of patients with acquired neurogenic language disorder by experts in clinical or educational fields through qualitative research methods based on the grounded theory. Methods: In-depth interviews were conducted with 10 speech language-pathologists who had experience in evaluating and managing adult patients and analyzed the data according to the procedures of open coding, axial coding, and selective coding. Results: Through the axial coding, the central theme that was revealed was 'although the importance of language analysis is recognized, it has not been actively implemented in the clinical field'. The causal conditions of this phenomenon were 'strengths and limitations of language analysis exist', 'insufficient education and experience for analysis', and 'difficulties associated with conducting language analysis.' 'Poor surroundings for language analysis' and 'less utilization of results' functioned as contextual conditions. The examples of speech language pathologists' action/interaction strategy were 'simple analysis of the utterances collected in the formal tests', 'no language analysis', and 'additional analysis conducted for some cases'. The intervening conditions were 'differences in views on the value of language analysis among adult subjects' and 'differences in experience and perception of various technology applications related to analysis'. The action/interaction consequences towards the phenomenon were 'demands for criteria and standard', 'needs to support multiple aspects related to language analysis', and 'recognition of limitation and reality compliance'. Conclusion: Through this study, we observed speech-language pathologists' current state, difficulties, and examined solutions regarding language analysis in the clinical setting.

Keywords: Adults, Neurogenic language disorders, Qualitative research, Grounded theory
신경언어장애는 선천적 혹은 후천적인 신경학적 원인으로 인해 언어의 형식, 내용 및 사용에서 어려움을 보이는 언어장애를 말한 다. 성인기에 발현하는 언어장애 즉, 후천성 신경언어장애의 대표적 인 증상인 실어증은 언어 습득시기 이후의 신경계의 손상에 기인 하며, 구어 측면인 말하기나 듣기뿐만 아니라 문어인 읽기와 쓰기 에서도 결함을 보이는 다중양식적인 양상으로 나타난다. 이를 유 발하는 주요 기저 질환은 뇌혈관 질환인 뇌졸중으로 알려져 있으
며(Godefroy, Bubois, Debachy, Leclerc, \& Kreisler, 2002) 최근에는 뇌혈관 질환과 더불어 치매나 파킨슨병 등 후천성 신경언어장애를 유발하는 퇴행성 질환과 관련된 환자의 수가 증가하면서 이들에 대한 관심이 높아지고 있다. 우리나라는 이미 2009년을 기준으로 65세 이상이 차지하는 비율이 $10.7 \%$ 에 달하였으며, 2018년 말에는 총인구 중 약 $15 \%$ 가 노인 비율에 해당하는 고령사회로 들어섰다. 향후 5년 후인 2026년에는 노인 인구 비율이 $20 \%$ 를 넘어선 초고령 
Ji Hye Yoon, et al. • A qualitative Study on Experiences of Language Sample Analysis for Adults

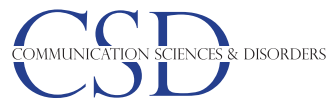

사회에 진입하고, 2045 년에는 그 비율이 $37 \%$ 에 달해 현재 대표적 인 고령 국가인 일본을 뛰어넘는 고령 국가가 될 것으로 예상된다 (Ministry of the Interior and Safety, 2019). 이러한 추세는 결과적 으로 임상현장에서 성인 언어장애 평가와 관련된 수요의 증가로 반영되며 임상가가 선택한 평가 방법과 절차는 이후에 이루어지는 중재 목표의 기반이 되므로 성인 신경언어장애 사례의 접근과 운영 과정 전반에서 매우 중요한 위치에 있다.

일반적으로 임상현장에서 활용되는 신경언어장애를 위한 검사 도구는 타 언어장애에서의 검사도구와 마찬가지로 크게 선별검사, 종합검사 및 심화검사로 나뉜다. 선별검사의 경우 언어장애에 대하 여 보다 빠르고 간편하게 진단하기 위하여 실시되는 검사로서, 표현 언어와 수용언어능력을 포함하며 소요시간이 3-10분정도로 짧은 검사이다. 현재 한국인을 대상으로 표준화된 선별검사도구에는 실 어증-신경언어장애 선별검사(Screening Test for Aphasia and Neurologic-communication Disorders, STAND; Kim, Heo, Kim, \& Kim, 2009)와 한국판 프렌차이 실어증 선별검사(Korean-Frenchay Aphasia Screening Test; Pyun, 2008)가 있다. 종합검사의 경우 표현 언어능력(말하기, 쓰기)과 수용언어능력(이해하기, 읽기)을 선별검 사에 비하여 보다 종합적으로 측정하며 이를 통해 실어증의 유무, 실어증 유형, 중증도에 대한 진단 및 예후, 관련 인지능력을 함께 측 정할 수 있다. 국내에서는 한국판 웨스턴 실어증 검사(Korean version of Western Aphasia Battery, K-WAB; Kim \& Na, 2012)와 한국 실어증 감별진단검사(Korean test of Differential Diagnosis of Aphasia; Park, 2006)가 표준화되어 사용되고 있다. 심화검사는 하나의 영역만을 심층적으로 확인하는 검사로서 국내에서는 이름대기 기 능을 확인하는 한국판 보스턴이름대기 검사(Korean version of Boston Naming Test, K-BNT; Kim \& Na, 1997)가 표준화되어 있다.

임상 상황과 검사 목적에 따라 다소 차이가 있을 수는 있으나 성 인 신경언어장애 환자의 경우 대부분 위에서 언급된 표준화 공식검 사 도구를 통하여 진단을 받게 된다. 국내의 성인 신경언어장애 환 자의 평가 및 치료를 담당하고 있는 언어재활사와의 심층면접을 통 해 임상 현장의 평가 실태를 파악한 연구(Kwon, 2007)에서는 앞서 제시된 검사도구나 절차 활용에 대한 실태를 확인하였다. 그리고 개발되어 있는 공식 검사도구로 해결되지 않는 영역을 파악하기 위 해서는 비공식 검사 방법을 활용해야한다고 제안하였다. 평가 상 황에서 주로 활용되는 비공식적 방법으로는 대상자 관찰, 보호자 인터뷰를 통한 정보 수집, 다양한 상황에서의 언어표본수집 및 분 석 등이 있다. 이 중 대상자의 발화를 수집하여 시행하는 언어표본 분석인 발화분석은 공식 검사에서 확인되지 않는 대상자의 자연스 러운 언어활동을 민감하게 반영한다는 측면에서 표준화 공식검사
의 단점을 보완하기 위한 방법으로 발화분석에 대한 필요성과 효 과는 그간 국내외의 아동언어장애를 대상으로 한 연구와 임상 현 장에서 활발히 증명되어져 왔다(Paul \& Norbury, 2012; Han \& Yim, 2016; Finestack, Rohwer, Hilliard,\& Abbeduto, 2020). 그러나 성인 연령대의 대상자가 높은 비율을 차지하는 후천성 신경언어장 애 분야에서의 발화분석 방법에 대한 모색은 국내의 경우 일부 연 구(Choi, 2015; Im, Kwon, \& Shim, 2001; Jin, Choi, \& Lee, 2016; Kwon, Kim, Choi, Na, \& Lee, 1998)를 통해서만 이루어졌으며 언어 재활사의 성인 대상자에 대한 발화분석 실태 및 인식에 대한 조사 는 상대적으로 부족한 실정이다. 이에 임상현장에서 아동 대상자 에서 발화분석이 가지는 가치나 발화분석에 대한 견해가 성인 대 상자에게 그대로 적용될 수 있는지 확인할 필요가 있다.

본 연구는 임상이나 교육현장에서 이루어지는 후천성 신경언어 장애 환자의 발화 평가 과정과 발화분석에 대한 전문가의 경험과 요구를 살펴보는 것에 주요 목적이 있다. 연구방법적 측면에서는 신경언어장애 환자들에 대한 전문가들의 발화분석 경험이나 실태 에 대한 선행 연구가 거의 전무한 상황이므로 특정 가설을 먼저 설 정하고 연역적 접근을 통해 이를 검증하는 방법보다는(Edmondson \& McManus, 2007) 심도 있는 인터뷰를 통해 본 연구의 목적 과 대응하는 의미 있는 이론개념들을 탐색하고 추출한 다음, 추출 된 개념들 간의 상호 관계적 양상과 도식을 파악하여 최종적으로 조직화하여 현상과 실태를 파악하는 귀납적 접근방식의 근거이론 (grounded theory)에 기반한 질적연구 방법(Strauss \& Corbin, 1990)으로 진행하는 것이 적합하다고 판단하였다. 이렇게 현실에 서 추출된 자료에 바탕을 두고 이론을 환원 및 추출해 내는 과정은 복잡하고 모호한 특정 사회현상을 개념들을 통해 간명하게 구조 화하여 독자로 하여금 직관적인 이해를 가능케한다는 점에서 의의 가 있다. Strauss (1987)가 고안한 '패러다임 모형'(paradigm model) 은 우리가 경험하는 대부분의 사회현상들은 중심현상, 인과적 조 건, 맥락적 조건, 중재적 조건, 작용-상호작용 전략, 결과의 '6가지 단계들'로 구성할 수 있고, 연구자는 자료의 코딩과정에서 식별된 개념들을 이러한 6 가지 단계 내에 배치하는 방식으로 연구를 진행 함으로써 분석의 모호성 및 연구자의 주관성을 개입하는 것을 최 소화 할 수 있다고 제안하였다. 특히 기존의 질적연구 방식에서 간 과되기 쉬웠던 연구자의 주관적 의견을 어떻게 다룰 것인가에 관한 문제를 연구 설계에 있어서 가장 중요한 고려사항으로 인식하였다 (Kwon, 2016). 이에 '패러다임 모형'은 근거연구에 있어서 매우 체계 적이고 직관적인 틀을 제시한다는 점에서 가장 빈번히 활용된다 (Vreede, Jones, \& Mgaya, 1998). 이에, 본 연구에서는 대상자들에 게 일대일 인터뷰를 시행하고 수집된 자료를 질적으로 분석하여 
임상 평가과정에서 언어재활사들이 직면하는 발화분석의 문제점 을 다각적으로 확인하고자 하였다. 그리고 발화분석 과정에서 확 인된 문제점들을 보완하고 해결하기 위한 개선방안을 살펴보았다.

\section{연구방법}

\section{연구대상}

질적 연구의 기준 표본 추출전략(criterion sampling strategy) (Hatch, 2002)에 의거하여 성인 대상자의 발화분석 실태와 문제해 결방안을 제시하는 본 연구의 주요 목적에 관해 충분한 정보를 제 공할 수 있는 참여자들로 구성되었다. 참여자의 선정기준은 1) 보 건복지부령의 언어재활사 자격증을 소지하고, 2) 후천성 신경언어 장애 환자를 평가하고 치료해 본 경험이 있는 임상경력 3 년 이상을 대상으로 하였으며, 3) 아동 환자와 비교하였을 때, 성인 환자에 대 한 풀타임의 임상경험이 전체 임상경험의 $50 \%$ 이상을 차지하는 경 우를 대상으로 하였다. 연구자는 주변 지인들을 통하여 위의 기준 을 만족하는 연구참여자를 소개받았으며, 이 중 연구에 대한 설명 을 듣고 자발적으로 참여하기를 동의하는 10 명의 참여자가 최종적 으로 참여하였다. 인터뷰 대상자의 평균 임상기간은 10.6 년이었으 며, 모두 1 급의 언어재활사 자격증을 가지고 있었다. 10 인의 참여자 중 3 인은 위의 조건과 더불어 대학에서 성인언어장애 관련 교과에 대한 8년 이상의 교수 경험이 있었다(Table 1).

\section{질문지 구성}

본 연구의 저자들은 연구목적에 부합하는 질문지를 구성하기 위하여 질적분석에 관한 기존의 선행연구(Hwang, Park, \& Kim, 2019; Kim \& Lee, 2013; Kwon, 2007)를 검토하여 초안을 작성하였 다. 작성된 초안은 질적연구를 직접 수행한 경험이 있는 1 인에 의하

Table 1. Information of participants responding to the interview

\begin{tabular}{lccccl}
\hline No & Gender & Age & Clinical career (yr) & Degree & Type of work facilities \\
\hline P1 & M & 31 & 5 & Master's & Hospital \\
P2 & F & 45 & 8 & Doctoral & University \\
P3 & F & 44 & 10 & Master's & University \\
P4 & F & 39 & 12 & Master's & Hospital \\
P5 & F & 35 & 12 & Master's & Private center \\
P6 & F & 34 & 7 & Doctoral & Private center \\
P7 & F & 50 & 15 & Master's & Private center/hospital \\
P8 & F & 36 & 12 & Master's & Hospital \\
P9 & F & 48 & 21 & Doctoral & Hospital \\
P10 & F & 43 & 4 & Doctoral & University \\
\hline
\end{tabular}

yr= year.
여 검토되었으며, 검토과정을 통하여 2차례에 걸쳐 초안이 수정되 었다. 1 차 수정 단계에서는 유사한 항목이 통합되었으며, 2 차 수정 단계에서는 항목(예: 발화분석에 대한 대안, 발화분석을 학습한 경 험)이 추가 보완되었다. 질문지는 총 5 개의 영역으로 구성되었다. 영 역 1 에는 본 인터뷰에 대한 간단한 소개가 포함되었다. 영역 2는 시 작질문 영역으로서 인터뷰 대상자의 경력, 관심분야, 자격증에 대 한 질문이 포함되었다. 영역 3은 전환질문 영역으로서 현재 담당하 는 사례현황과 평가의 절차 및 장단점을 확인하는 질문으로 구성 되었다. 영역 4 는 핵심질문 영역으로서 발화분석의 현황, 발화분석 의 필요성 및 의의, 발화분석과 관련한 문제점 해결을 위한 극복방 안을 묻는 질문들로 구성되었다. 영역 5는 마무리로서 질문에 포함 된 내용 이외에 인터뷰 대상자가 발화분석에 관하여 추가적으로 이야기하고 싶은 내용을 자유롭게 이야기할 수 있도록 하였다. 질 문지의 대부분의 항목은 참여자가 자유롭게 의견을 개시하는 개 방형 질문으로 구성하였다. 핵심질문 영역부터 시작되는 개방형 질 문을 유도하기 위하여 그 이전 영역인 전환질문 영역에서는 폐쇄형 질문이 일부 포함되었다. 실제 인터뷰 상황에서는 질문지의 순서를 고수하기 보다는 참여자의 응답에 따라 자유롭게 순서가 변경되어 사용되었다.

\section{자료수집 및 전사}

본 연구의 인터뷰는 2020년 1월 17일부터 2월 21일까지 약 1 개월 간 이루어졌다. 인터뷰 내용과 반응의 일관성을 위하여 제 1 연구자 가 모든 참여자의 자료 수집을 진행하였다. 참여자와의 최초 연락 단계에서 제 1 연구자는 본 연구의 목적과 배경에 대하여 설명하였 고 연구 참여를 희망하는 경우에 인터뷰 장소와 시간을 정하였으 며, 인터뷰에서 사용될 질문지를 참여자에게 메일로 전달하여 질 문들을 충분히 검토할 수 있도록 하였다. 대상자의 자료수집은 연 구자와 참여자가 1:1인 상황에서 소음이 없는 독립된 공간(치료실, 연구실, 회의실, 스터디 공간, 자택)에서 진행되었다. 본 인터뷰를 시 작하기 전에 약 5-25분간의 라포 형성 시간을 가졌다. 라포 형성 단 계에서는 연구자와 참여자가 연구 목적을 포함해서 보다 자유롭게 연구에 대하여 질문하고 응답하는 시간을 가졌다. 시작질문 영역 에서는 인터뷰 대상자의 임상경험이 다양한 경우 우선적으로는 가 장 최근의 임상경험에 기준하여 응답하도록 하였으며, 추가적으로 예전의 임상경험에 대해서도 답할 수 있도록 하였다. 본 인터뷰에서 는 제시되는 문항에 대하여 참여자가 경험하거나 그간 생각해왔던 내용들을 자유롭게 이야기하도록 하였으며, 참여자의 이야기 흐름 에 따라 심층 질문이 더해지기도 하였다. 모든 문항이 끝난 후 연구 자는 질문지를 검토하여 누락된 질문이 없는지 확인하였으며, 추가 
적으로 본 인터뷰와 관련하여 참여자의 개인적인 질의나 추가 견해 를 이야기할 수 있도록 참여자에게 시간을 제공하였다. 본 인터뷰 는 $\mathrm{P} 1$ 인 당 1 회씩 이루어졌으며, 라포형성을 제외하고 약 60 분에서 82 분의 인터뷰 시간이 소요되었고, 평균 인터뷰 시간은 71.2 분 이었 다. 모든 자료는 녹음기(Sony ICD-UX560)로 녹취되었으며, 모든 인터뷰 자료는 자료수집 1주일 이내에 Microsoft Word에 전사하였 다. 글자체는 함초롱바탕, 글자크기는 10 , 줄간격은 160 , 한페이지 44 줄로 작성하였을 때, 총 분량은 $\mathrm{A} 4$ 용지로 171 장이었다.

\section{자료분석}

수집한 정보로부터 결론을 이끌어내기 위하여 전사된 자료는 근 거이론의 접근방법 중 방대한 정보의 복잡성을 단계적으로 완화해 가는 과정에서 널리 활용되는 코딩 과정인 개방코딩(open coding), 축코딩(axial coding), 선택코딩(selective coding)의 순서로 분석되 었다(Strauss \& Corbin, 1990). 개방코딩(open coding) 단계에서는 연속적 비교법(constant comparative method)에 따라 전사된 내용 을 읽으면서 각 문장을 대표하는 주요한 의미나 의도를 최초로 개 념화하는 작업을 통해 명칭을 부여하였다. 이 과정에서는 먼저 10 개의 전사본 중 2 개를 임의로 선택하여 제 1 연구자와 공동연구자 2 인이 각자 독립적으로 개념화하는 작업을 실시하였다. 독립작업 후 1 회의 오프라인 논의를 거쳐 첫 번째 코딩북을 작성하였다. 그 다 음 과정으로는 제 1 연구자가 나머지 전사본들을 첫 번째 코딩북의 코드를 활용하여 코딩하고 기존의 코드들을 통합 및 수정하는 과 정을 거쳐 두 번째 코딩북을 작성하였다. 이렇게 작성된 코딩북으 로 2 차례의 오프라인 및 온라인 논의를 통하여 개념, 하위범주, 범 주가 도출되었다. 축코딩 단계에서는 제 1 연구자가 개방코딩 단계에 서 개념으로 명명되어 분해되었던 자료를 범주들의 속성에 따라 재 조합하고 하위범주들과의 관계를 파악하여 내재적 관계를 살펴볼 수 있는 모형을 1 차적으로 도출하였으며, 그 결과를 1 회의 온라인 논의를 통하여 2 인의 공동연구자와 함께 본 모형을 검토하고 수정 하였다. 선택코딩 단계에서는 제 1 연구자가 축코딩을 통해 선정된 범주들 간의 관계를 핵심범주를 근간으로 통합하면서 1차적으로 수정 및 보완하였으며, 그 결과를 1 회의 온라인 논의를 통하여 2 인 의 공동연구자와 함께 도출된 개념, 개념의 체계적 연결, 범주화 과 정에 대한 검토 및 수정과정을 거쳐 최종 합의점을 도출하였다.

\section{연구의 신뢰도}

면담이 끝난 후 전체 참여자의 $50 \%$ 에 해당하는 5 인의 참여자에 게 전사 내용을 요약하여 메일로 전달하였으며, 그 내용에 대하여 수정하거나 추가할 내용이 없는지 확인(member check)하였다. 그
결과, 수정이나 추가할 내용이나 왜곡된 부분은 없는 것으로 확인 되었다. 제 1 연구자는 녹취된 음성파일과 석사생이 전사한 내용을 대조하였으며 오타를 제외하고는 $100 \%$ 의 일치율로 전사된 것을 확인하였다.

\section{연구결과}

\section{개방코딩 결과}

녹취한 인터뷰 내용을 전사한 원자료에 대해 개방코딩한 결과 총 96 개의 개념, 25 개의 하위범주 및 14 개의 범주가 도출되었다. 자 세한 내용은 Appendix 1에 제시하였다.

\section{축코딩 결과}

성인언어장애 환자의 발화분석과 관련한 답변의 개념과 하위범 주들간의 관계를 파악하여 그 내용을 중심현상, 인과적 조건, 맥락 적 조건, 중재적 조건, 작용/상호작용 전략, 결과의 측면에서 재구성 하고 이를 요약하여 Figure 1과 같은 모형을 도출하였다.

\section{중심현상}

중심현상은 참여자들이 현재 겪고 있거나 경험하고 있는 현상에 대한 것으로서 다음에서 서술할 인과적 및 맥락적 조건의 영향을 받아 발생한다(Strauss \& Corbin, 1990). 언어재활사들은 발화가 환자의 자연스러운 언어능력을 반영하고 중재의 근거가 되므로 '발 화분석의 중요성은 인식하지만 임상현장에서 적극적으로 시행하 지 못함'이 중심현상으로 확인되었다.

- 발화는 환자의 가장 자연스러운 언어이고, 형식적인 틀에서 나오 는 언어가 아니라, 환자가 실질적으로 일상생활에서 쓰는 언어들 을 가지고 그 안에서 치료의 문제점도 찾고 그 안에서 해결점을 찾 는 것이기 때문에 발화분석은 중요하다고 봐요. (P8)

- 병원세팅에서는 표준화된 검사들을 우선 시행하기 때문에 늘 추가적으로 발화분석을 시행하지는 않아요. (P4)

\section{인과적 조건}

인과적 조건은 현상이 발생하도록 이끄는 직접적 원인이나 사건 으로 구성된다(Strauss \& Corbin, 1990). 본 연구에서 중심현상인 '성인 대상자에서 발화분석의 필요성은 인식하지만 임상현장에서 적극적으로 시행하지 못함'을 유발하는 인과적 조건은 ‘발화분석 의 강점과 제한점이 공존, '성인 발화분석에 대한 교육 및 경험의 부족, '발화분석의 시행과 관련된 어려움으로 나타났다. 


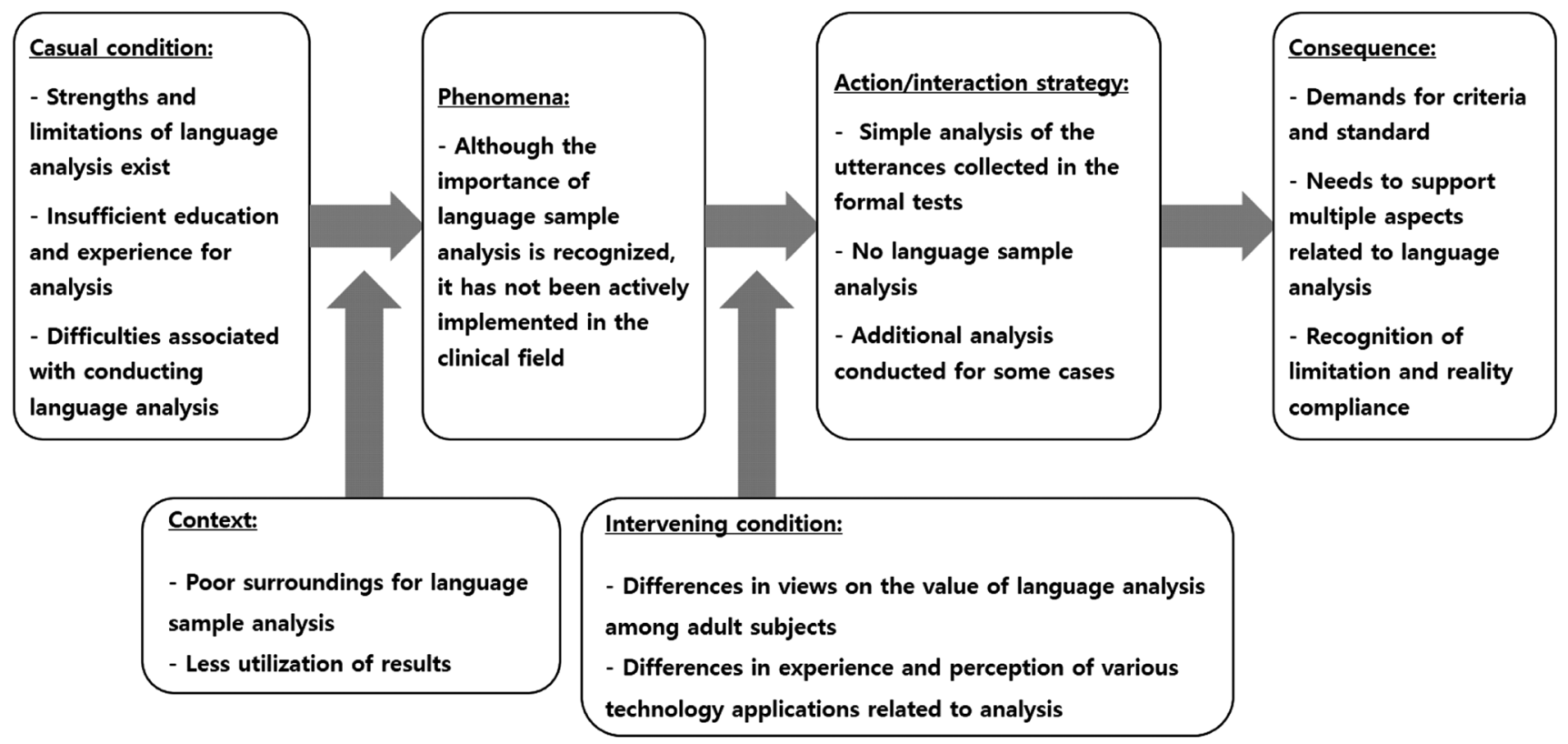

Figure 1. Speech-language pathologist' response toward language sample analysis for adult patients with acquired neurogenic language disorders.

발화분석의 강점과 제한점이 공존

언어재활사들은 성인언어장애 환자의 평가를 위하여 주로 표준 화 공식 검사(K-WAB, STAND)나 표준화된 심화검사(K-BNT)를 사용하고 있었으나 이러한 공식검사는 인지전반이나 미세한 능력 의 변화를 탐지하지 못하며, 결함을 경미하게 보이는 환자나 점수 상 분류기준에 부합하지 않는 환자가 관찰될 경우 그에 대한 정보 를 제공하는 측면이 부족한 제한점이 있기 때문에 발화분석이 이 러한 공식 검사의 단점을 보완하면서 가장 자연스러운 실생활의 발화특성을 확인할 수 있고, 특히 중증도가 경한 환자나 실어증 이 외의 인지언어의 문제를 확인하는데 있어 용이하다고 하였다. 또한 발화분석은 중재목표의 선정이나 중재효과 확인에 도움을 주며, 장애진단이나 치료처방을 위한 보충 증빙자료로 활용하는 강점을 가진다고 하였다.

- 공식 검사의 단점은 비공식 검사를 통해서 파악 할 수 있는 부분 들을 알기 어렵다는 거죠. 특히 성인같은 경우에는 현재 성인 신 경언어장애를 평가하는 도구가 치매나 경도인지장애와 같은 인 지의사소통장애 환자들을 평가하는 데 필요한 요소들을 가지 고 있지 못하기 때문에 추가적인 비공식적인 검사나 담화 등을 통해서 확인해야하는 것이지요. (P2)

- 공식 검사의 난이도가 높지 않기 때문에 중증도가 경한 환자의 경우에는 거의 만점을 받으시는 경우가 있고 반대로 정말로 발화 가 거의 없으신 심한 환자분들도 공식 검사 하기가 힘들었죠. (P6)
- 치료에서는 중간 점검 개념으로 발화를 샘플링하는 것은 필요한 것 같아요. 제가 지금 하고 있는 치료가 제대로 진행이 되고 있는 지, 전이개념은 아니더라도 치료가 제대로 흘러가고 있는지에 대 한 것을 확인하기 위해서는 $\cdots$ (중략). (P3)

- 의사들 같은 경우에는 AQ (aphasia quotient, 실어증 지수)가 90 점 가까이 되면 치료 안해도 된다고 생각하고 치료처방을 안 내 시거든요. 환자는 너무 힘들어 하시는데. 그렇기 때문에 그 분들 을 위해서도 공식 검사에서는 이렇게 나왔지만 발화나 담화에서 어려움을 여전히 보이고 있음을 표현해줄 필요가 있어요.(P9)

반면에 발화분석이 가지는 제한점에 대해서도 많은 의견을 산출 하였다. 표준화검사는 언어장애 유형이나 중증도를 전반적으로 파 악하는데 용이하며 수행력과 비교 가능한 규준이 제공되지만 발 화분석의 경우 분석기준이 명확하지 않고, 비교규준이 존재하지 않아 해석이 어렵다고 하였다. 또한 발화분석에 대한 통일된 과제 나 절차가 없으므로 평가자 간 신뢰도가 확보되지 않는다는 점도 지적하였다.

- K-WAB은 신경언어장애 검사 중에서 표준화된 검사이기 때문 에 이를 기준으로 명확한 진단을 내릴 수 있고 $\mathrm{AQ}$ 라는 점수가 명확하잖아요? 그렇기 때문에 환자분이나 의사에게 설명할 때 도 편해요. 100 점 만점에서 삼십몇점 맞으셨어요 하면 환자분이 느끼기에도 '나 삼십몇점 맞았으면 나 진짜 못했구나’ 이렇게 생 
각하시거든요. 진전같은 것을 비교해 볼 때도 비교가 쉽게 되니 까좋은 도구인 것 같아요. (P4)

- 비공식 평가같은 경우에는 규준이 명확하지 않다는 점 때문에 서로 정량화해서 비교하기가 힘들다는 것이 어려운 점이고요. 아동같은 경우에는 발화분석에 대한 어떤 결과물들이 좀 많이 있는 편인데, 성인같은 경우에는 그런 게 좀 많이 부족하기 때문 에 비교 분석할 만한 것이 상대적으로 적은 편이죠... 정량화된 자료, 기준, 규준 같은 게 없기 때문에 임상에서 그 결과를 어떻 게 해석할지를 모르고요. (P2)

- 일단은 프로토콜화 되어있는 표준화검사처럼 정해져 있는 것이 아니니까 저도 풍문으로 듣고 이것저것 해보면서 과제도 처음에 는 '토끼와 거북이 이야기 해주세요' 이랬는데, 다른 선생님께서 듣고 그건 너무 쉬운 거 아니냐고 하시면 '흥부와 놀부 이야기 해 주세요' 이렇게 조언해주시는 거에 따라서 왔다 갔다 과제를 바 뀌보고 그러다 보니까 결과지에 '수필 다시말하기 과제에서 이 정도의 수행력을 보였다라고 썼을 때 사실 다른 사람들은 이게 무엇을 했고 어떤 수행력에 관한 것인지를 잘 모를 것 같다라는 생각을 했어요. (P6)

성인 발화분석에 대한 교육 및 경험의 부족

중심현상을 유발하는 두 번째 인과적 조건으로는 아동과 비교 하여 성인 발화분석에 대한 교육 및 경험이 부족하다는 것이 확인 되었다. 대부분의 참여자들은 과거 학부나 대학원의 교육과정과 기타 교육과정(보수교육이나 세미나) 등을 통하여 아동 대상자의 경우 발화 수집에서 분석에 이르기까지 실습을 통해 자세하게 배 웠으나 성인 대상자의 발화분석 과정에 대해서는 교육받은 경험이 대부분 전무하거나체계적으로 교육받지 못한 것으로 파악되었다.

- 학부 때 아마 언어발달, 언어발달장애, 뭐 조음음운장애 시간에 아동을 대상으로 100 발화를 수집하고 전사하고 형태소, 어휘, 전체 단어 수 이런 자세한 지표들을 다 개수를 세서 발화분석을 했어요. 아동은 발달 기준이 있었기 때문에 거기에 비교를 해서 이 아동은 또래에 비해서 뭐가 더 부족하고 규준에 비해서 어느 정도에 해당되고 이런 것들 배웠어요. (P1)

- 아동에서는 전사하는 법도 자세히 배우고 실습도 하고 그랬었는 데 성인 발화분석에 대해서는 교과과정에서는 배운 기억이 없고 제가 치료실습 받을 때 수퍼바이저 선생님들께서 하시는 것을 어깨너머로 보면서 배운 것 같아요. (P6)
발화분석의 시행과 관련된 어려움

중심현상을 유발하는 세 번째 인과적 조건으로는 발화분석 시 행과 관련된 어려움이 관찰되었다. 이러한 어려움으로는 특히 전사 및 분석을 위해 많은 시간을 투자해야하는 것을 꼽았으며, 성인언 어장애 환자의 특성 상 마비말장애 등을 동반하거나 허구어나자 곤(jargon)을 산출하는 경우가 많아 언어재활사가 시행하는 전사 의 정확성에 대한 신뢰도의 문제가 발생할 수 있음을 지적하였다.

- 시간과 노력이 너무 많이 드는거죠. 하루에 여덟 세션, 열 세션, 열 두 세션 이렇게 하면서 매번 발화분석을 자세히 할 수는 없겠 죠. 분석하려면 전사도 당연히 해야하고요. 우리가 학교에서 배 울 때처럼 형용사 몇 개, 안긴문장 몇 개, 형태소는 몇 개, 평균발 화길이(mean length of utterance, MLU)는 몇 개, C-UNIT은 몇 개 이렇게 분석하는 것은 불가능하다고 봐요. (P8)

- 제일 큰 문제는 그거 할 시간이 없어요. 예를 들면 자기가 하루 여덟 시간의 근무 시간 안에 정해진 세션 수가 있는데, 그 안에 발화분석을 하려면 시간 외적으로 하는 방법밖에 없는데, 굳이 따로 개인시간을 들여가면서 추가업무를 하지는 않는 것으로 알 고 있습니다. (중략) 치료 선정, 치료 구상, 평가지 정리, 발화분석 시간 이런 것들을 위한 시간이 근무 시간 내에 보장이 된다면 모 르겠지만...(중략) 병원은 환자가 빠져나가고, 퇴원하고, 언제 신 환이 들어올지 등의 변동성이 심하고, 모든 세션이 꽉 차면 화장 실 갈 시간도 부족한데 굳이 발화분석을 하게 될까 그렇게 생각 하고 있습니다. (P1)

- 환자가 되게 말속도가 빠르다거나 아니면 빠르지 않더라도 논리 적으로 말을 못하는 사람들의 말을 받아 적을 때는 오히려 더 어 렵더라고요. 이를테면 맥락이 잘 통하면 저희가 어느 정도 예측 을 하면서 받아 적을 수가 있는데 환자가 치매나 베르니케 실어증 환자처럼 엄청 많은 말을 하는데 말의 효율성이 떨어지고 환자 말 이 여기로 갔다 저기로 갔다 하니까 적는 사람 입장에서 맥락이 없는 말을 할 때 받아 적기가 어려워요. 발음이 좀 부정확할 때도 무슨 소리인가 잘 못 알아듣기도 하고요. (P7)

\section{맥락적 조건}

맥락적 조건은 중심현상에 간접적으로 영향을 주는 조건의 집합 으로(Strauss \& Corbin, 1990) 본 연구에서는 '열악한 임상환경'과 '발화분석 결과의 활용도 저하'가 임상현장에서 성인 대상자에게 발화분석을 적극적으로 시행하지 않는 중심현상에 영향을 미치는 맥락적 조건으로 파악되었다. 


\section{열악한 임상환경}

발화 전사와 분석을 위한 시간이 오래 걸리는데 반해 의료수가 로 반영되지 않으며, 처방코드도 없기 때문에 이를 시행할 수 있는 환경이 구비되지 않았음을 지적하였다.

- 세팅이 병원이다 보니까 아무래도 주치의나 교수님께서 처방을 내주셔야지 검사를 할 수가 있는데 처방코드가 없어요. 그래서 코드가 있는 표준화된 검사들을 하니까 따로 발화분석을 추가 적으로 더 시행해야 할 필요성을 느끼지 못했던 것 같아요. (P4)

\section{발화분석 결과의 활용도 저하}

공식 검사를 통해 대상자의 상태나 언어적 진단명을 확인할 수 있는 유용성에 비해 발화분석의 유용성은 크지 않으므로 추가적 으로 시행하더라도 결과지에는 자세히 명시하지 않는 편이라고 하 였다. 또한 기타 전문가(의사)들의 발화분석에 대한 이해도나 관심 이 낮고, 의사소통에 있어 큰 의미를 가지지 못하므로 언어재활사 본인이 참조하거나 환자 및 보호자 상담 시에 약간 활용하는 정도 라고보고하였다.

- 어쨌든 병원세팅에서는 최종 검사결과를 의사가 통지를 해줘야 되는 거니까 저는 평가만 하고 의사에게 결과를 듣도록 환자를 보내게 되어 있는데, 제가 결과지에 기술을 자세히 하고 코멘트 를 쓴다고 해도 결국에는 공식 검사 점수만 보고 진단명이랑 중 증도에 대한 설명만으로 끝나는 경우가 더 많더라고요. (P8)

- 의사분들이 발화 검사나 분석 자체를 모르시는 경우도 있고 아 예 관심이 없는 경우도 많거든요. (P4)

- 사설센터 상황이면 언어재활사 선생님들끼리 그런 부분들이 공 유가 되잖아요. 그런데 병원세팅에서는 이걸 꼭 해야된다라고 말씀을 드려도 사실 공감이 안되고 $\cdots$ 공감이 안되다 보니까 물 리치료사 같은 경우는 하루에 12 세션에서 13세션 이상을 보니 까 약간 비교도 되는 거죠. 차라리 ‘왜 저렇게 저런걸 분석을 하 고 있을까? 저 시간에 환자를 더 보지. 이런 분위기가 많이 형성 되있어서 $\cdots(\mathrm{P} 8)$

- 제가 기록하는 의미는 있기는 하겠지만 다른 치료사나 의사들 과 이 결과를 공유하는 것이 의미가 있을까 라는 생각을 해요.

(P6)

\section{중재적 조건}

중재적 조건은 중심현상의 강도에 변화를 주는 조건으로써 작 용/상호작용 전략을 촉진하거나 방해하는 역할을 하는 것을 말한
다(Strauss \& Corbin, 1990). 본 연구에서 발화분석을 적극적으로 시행하지 못하는 중심현상과 이를 극복하기 위한 전략 사이에서 영향을 주는 중재적 조건으로 '성인 대상자에서 발화분석의 가치 에 대한 견해차이'와 '발화분석과 관련된 다양한 기술활용에 대한 인식의 차이'가 파악되었다.

성인 대상자에서 발화분석의 가치에 대한 견해차이

성인 환자의 경우 발화분석을 반드시 시행해야 할 경우가 많지 않으며, 특히 노년층 환자의 경우에는 정상노화로 인한 감퇴와 병 리로 인한 감퇴를 구분하기 어렵기 때문에 발화분석의 가치에 대 해서는 견해의 차이가 존재하였다.

- 문장을 말할 수 있는 사람은 언어치료실에 잘 안 오지 않나요? 또 브로카실어증 수준으로 말씀을 못하신다면 그 분들은 발화 를 분석하고 말고 할게 없는 상황인거죠. 병원에 오시는 실어증 환자는 발화분석을 할 만큼 문장단위로 길게 말하는 사람들이 많이 없죠. (중략) 물론 아주 경한 장애를 보이는 실어증 환자나 공식 검사에서 문제가 두드러지지 않는 우뇌손상 환자가 '내가 옛날 같지 않아'하고 오시는 분이 있다면 그분들에게는 발화분 석으로 접근을 하는 것이 중요할 것 같아요. 그런데 우뇌손상 환 자는 본인이 문제가 없다고 생각하는 경우도 많아서 언어치료실 에 오지 않고, 외상성 뇌손상 환자도 담화수준으로 발화를 못하 는 경우가 많은데다가 만약 담화수준으로 발화를 할 정도로 경 하다면 그 사람은 아마 발화의 문제가 있다기 보다는 마비말장 애를 검사하고 치료하고 싶은 젊은 환자가 아닐까요. (P10) - 만약 규준이 있다고 해도, 한편으로는 산출된 문장에서 '형태소 개수가 몇 개이다'라는 것이 성인에게 무슨 의미가 있는가 하는 생각도 합니다. 그렇게 발화분석을 자세하게 해도 관찰되는 그 런 지표나 개수들이 성인한테서는 의미가 없다고 생각하거든요. 노화가 오면 능력이 어느 정도는 떨어지잖아요. 그것을 병이랑 구분하기도 어려운거죠. $(\mathrm{P} 1)$

- 만약에 발화분석을 자세히 한다고 하더라도 아동과 같이 발달 상 어떤 표지들을 산출해야 하는데 이것을 못했으니 어느 수준 이다라고 말하는 것과 성인의 상황은 다르니까요. 성인은 이미 습득한 것이 병에 의해 손상된 거고 그 손상은 나이 순서대로 오 는 것이 아니고 노화로 인한 퇴행도 동일한 것이 아니라 사람마 다 들쭉날쭉 하잖아요. 그래서 성인에서 발화분석은 중요할 수 는 있지만 필수적이지는 않은 것 같아요. (P10) 
발화분석과관련된 다양한 기술활용에 대한 경험과 인식의차이

두 번째 중재적 조건으로는 발화분석과 관련된 다양한 기술 활 용에 대한 관심도에 차이를 보이는 것이 파악되었다. 모든 참여자 들은 특히 음성 인식 기술을 활용한 'siri'나 'google' 등을 알고는 있었지만 목적을 가지고 발화수집 과정에 이를 활용해본 적은 없 다고 응답하였다. 과반수 이상의 참여자들은 발화분석에 도움을 줄 수 있는 대안 중 하나로써 컴퓨터나 앱 활용과 같은 과학기술활 용에 대해 들어본 적이 있었고, 그 중 소수는 이러한 기술을 발화수 집이나 분석에 활용해 본적도 있었지만 지속적으로 사용하거나 현 재 사용하고 있는 참여자는 없었다. 사용하지 않는 이유로는 이러 한 기술에서는 전사 및 기초작업(발화 구분) 등을 임상가가 직접 해야하기 때문에 수기로 분석하는 것과 비교하여 편리성 측면에서 의 이점이 없기 때문이라 응답하였다. 또한 일회성으로 사용하였 을 때 오류가 많이 발생하였던 것으로 기억하고 있어서 신뢰도가 낮기 때문이라 응답하였다.

- 내가 하는 거보다 편해야 컴퓨터 프로그램을 쓰는 거거든요. 기 존 프로그램이 전사부터 완벽하게 자동으로 해주는 게 아니라 내가 워드에 전사하고 발화를 구분하고 언어적 지표를 분석한 후 수기로 세는 것에서 그 횟수를 단순히 셈만 해주는 정도라면 그냥 내가 뭐 하고 말지 꼭 컴퓨터를 사용해야 할까요? (P10) - 기억은 잘 안 나는데 어쨌든 발화를 워드에 타이핑을 하고 발화 를 구분해서 잘라주는 것도 우리가 하고 그랬던 것 같아요. 그래 서 무슨 워크샵 같은 데서 한 번 듣고 '어머 이거 더 힘들겠네’ 그 런 생각을 하고만 왔지 써보지는 않았어요. (중략) 워크숍참석 전 에는 '이제 쉬워지겠다' 그러고 가서 교육을 들었는데, 제가 손으 로 빨리빨리 하는 것보다 일단은 시간이 더 오래 걸렸어요. (P9) - 약점은 신뢰도를 믿을 수 없다는 것이었어요. 예를 들면 siri, 오 케이 구글, 지니 등의 음성 인식 프로그램이 잘 된다고 해도 해보 면 $100 \%$ 의 성공률을 보이는 것이 아니라 우리 말도 잘못 알아듣 는 경우가 종종많은데 $\cdots(\mathrm{Pl})$

\section{작용/상호작용 전략}

작용/상호작용 전략은 중심현상에 대응하기 위해 취해지는 대상 자들의 의도적 반응으로 상황을 조절하고 대처하는 행위이다(Strauss \& Corbin, 1990). 임상현장에서 성인 대상의 발화분석 시행에 대한 곤란을 해결하기 위한 전략은 크게 세 가지로 '공식검사를 통해 수 집된 발화를 약식으로 분석함', '발화분석을 따로 시행하지 않음', '경우에 따라 추가적으로 발화분석 시행함'으로 나타났다. 추가적 으로 확인된 발화전사의 방법에 관해서는 실시간 전사를 하면서
녹음이나 녹화를 하는 경우가 과반수 이상이었으며, 실시간 전사 만 하는 경우는 과반수보다 적었으나 그 비율에서는 크게 차이가 나지 않았다.

공식검사를 통해수집된 발화를 약식으로 분석함

대부분의 참여자들은 신경언어장애 환자의 경우 공식 검사 $(\mathrm{K}-$ $\mathrm{WAB}$ 의 스스로말하기 항목)를 통해 수집된 발화를 약식(관찰하 고 싶은 일부 지표 위주로 전반적 소견을 확인함)으로 간단히 분석 하고 있었다.

- 따로 발화수집을 하지는 않고 K-WAB 스스로 말하기 부분 에서 환자분에게 질문을 하고 환자분이 대답하는 거랑 환 자분한테 그림을 보여주고 설명해보라 하는 과제가 있잖아 요. 그거 사용해서 발화 수집하고 환자의 전반적인 소견에 따라서 일부 중요한 지표들이 산출되는지 오류는 없는지 등을 간단히 보고 판단해요. 개수는 세지 않아요. (P4)

발화분석을 따로 시행하지 않음

일부 참여자들은 발화분석을 따로 시행하지 않는다고 응답하였 으며, 언어장애 진단만을 위하여 스스로말하기의 채점기준에 따라 유창성 측면, 문법적 측면, 내용적 측면의 척도에 따라 채점하고 있 다고 하였다.

- 병원에서는 K-WAB에서 요구하는 점수를 내는 것이 목적이니 까 스스로말하기 점수를 낼 수 있도록 기준에 따라 내용 점수, 유창성 점수 이런 것만 내지요. (P7)

\section{경우에 따라추가적으로 발화분석 시행함}

일부 참여자들은 우반구손상, 외상성 뇌손상, 치매 환자 등 담화 평가가 중요한 일부 환자에 한하여 추가적인 과제를 통해 발화수 집 및 분석을 실시한다고 응답하였으며 추가적인 과제로는 주로 이 야기하기, 이야기 듣고 다시말하기, 원인결과설명, 문단 읽고 요약 해서 말하기를 시행하고, 얻어진 자료를 이야기문법, 주제유지, 응 집성 등의 화용적 측면에서 개수를 세는 등으로 비교적 자세히 분 석한다고 하였다.

- 환자에 따라서 원인, 결과를 설명할 수 있는 그림을 보여주거나 흥부 놀부 이야기하기, 문단을 읽게 하고 요약하게 하는 과제를 통해 환자에게 발화를 유도해서 이야기 문법 같은 것을 분석하 고주제를 잘 유지하는지 등을 분석해요. (P9) 


\section{결과}

결과는 현상을 해결하기 위해 취해진 작용/상호작용 전략에 따 라 발생하는 것이다(Strauss \& Corbin, 1990). 앞서 제시된 전략들 을 통해 '성인 발화분석의 기준과 규준 마련에 대한 요구' '발화분 석과 관련된 다각적 측면의 지원에 대한 요구', '한계점 인식 및 현실 순응'이 결과로 도출되었다.

\section{성인 발화분석의 기준과 규준 마련에 대한요구}

전략에 따른 첫 번째 결과는 성인 발화분석의 기준과 규준 마련 에 대한 요구'로 관찰되었다. 먼저 성인 대상자에게 중요한 주요 발 화지표에 대한 기준을 정립하는 것과 관련하여 참여자들은 연령에 따른 발화분석의 중요도에 대한 견해에서 차이를 보였다. 아동과 성인에게 동일한 정도로 중요하다고 답한 참여자와 성인보다 아동 에게 더 중요하다고 답한 참여자의 비율은 동일하였다. 아동에서의 발화분석이 중요한 이유는 언어적 지표가 발달과정을 반영하기 때 문이며 학습에 영향을 미친다고 생각하였다. 성인에서 발화분석이 중요한 이유로는 실생활에서 사용되는 표현을 반영하기 때문이라 응답한 참여자도 있었으나 개인차나 환경의 영향이 크고, 성인의 발화능력은 의사소통의 효율성 측면에서 판단해야 하므로 아동과 는 다른 발화분석 기준과 지표가 적용되어야 한다고 언급하였다. 성인의 발화에서 주요한 분석의 지표로는 문법형태소 사용능력에 대한 언급이 가장 많았다. 성인발화 규준 마련에 대한 요구로는 근 거를 마련하기 위해 성인 대상의 다양한 연구가 선행되어야 한다고 도 역설하였다.

- 일단 아동과 성인은 오류 양상이 다르기 때문에 발화분석을 하 는 의미자체가 다르다고 생각이 들어요. 또한 아동의 발화분석 방법은 성인의 언어형태에는 어울리지 않는 분석이라고요. 왜냐 하면 발화분석의 규준이라고 나온 것들은 발달적으로 뭐가 출현 했다 아니다를 비교하는 건데 그러기 위해서는 어떤 묵시적인 규 준이 있는 거고 발달연령라는 것이 있는 건데, 성인은 발달연령 순으로 퇴화하는 게 아니잖아요. 또 실어증의 경우는 습득한 부 분에 대한 효용성이 저하된거라 하루 안에서도 변화가 있을 수 있고, 오늘은 못해도 내일은 할 수 있는거고 $\cdots(\mathrm{P} 10)$

- 아동같은 경우는 학습에 관련된 언어를 평가하는 필요성도 있 으니까 어디까지 습득을 했는지가 중요한데, 성인 같은 경우에는 지금 새롭게 배우는 것이 아니라 이미 있던 거를 얼마나 본인이 인출 해낼 수 있는지, 얼마나 효율적으로 사용할 수 있는지가 중 요하고, 세부적인 지표가 중요하다기보다는 그야말로 본인의 의 사를 얼마나 효율적으로 나타낼 수 있느냐가 더 중요하다고 생
각을 해서 오히려 짧은 문장으로라도 본인이 말하고 싶은 내용 을 충분히 전달할 수 있으면 문법형태소가 부족하거나 문장의 길이가 짧다고 해서 이상이 있다고 생각하지 않아요. (P6)

- 발화길이가 짧으신 분들은 발화할 때 주로 몇 어절 발화를 사용 했다고 확인하는 것이 중요한데, 발화길이가 길어서 4 어절 이상 넘어가는 분들에서는 이런 발화분석 지표는 별로 의미가 없어 요. 그리고 성인에게서는 단순히 개수가 중요하기 보다는 조사나 문법적인 오류가 있는지 없는지를 전반적으로 확인하는 것이 더 중요한 것 같아요. (P9)

- 우선 정상인들의 발화들을 샘플링해서 그걸 분석하면 횔씬 쉽 잖아요. 거기서 정상 규준도 만들고 연구도 하고 그래야지 $\cdots(\mathrm{P9})$

- 발화분석에 대한 연구가 좀 많았으면 좋겠어요. 요즘에는 중, 고 등학생 정도의 언어연령이 딱 되면은 검사할 수 있는 게 표준화검 사는 REVT (Receptive Expressive Vocabulry Test, 수용 표현 어 휘력 검사) 정도 말고는 거의 없어요. 언어연령이 그렇게 됐을 때. 아이가 이제 13세 넘어가고 언어연령이 그 정도 까지도 올라가면 그 다음에는 그냥 굉장히 학습적인 것으로 넘어가더라고요. 성인 의 범주를 좀 넓게 잡아서 10 대 후반부터 해가지고 노년기까지 포 함하는규준들이 더 많이 연구되었으면...(P5)

발화분석과 관련된 다각적 측면의 지원에 대한 요구

전략에 따른 두 번째 결과로 '발화분석과 관련된 다각적 측면의 지원에 대한 요구'가 이어졌다. 먼저 현장에서는 성인의 발화분석 과 관련된 기초에 대하여 전반적이고 체계적인 재교육이 이루어지 기를 기대하였다. 그리고 컴퓨터, 앱, 클라우드 시스템 등 과학기술 을 활용하여 미래에는 지금보다 편리하게 발화분석을 시행할 수 있 길 바라는 기대감과 긍정적 태도가 관찰되었다. 그러나 동시에 첫 번째 결과로 언급되었던 내용과 동일한 맥락에서 과학기술적 지원 시에도 성인에게 중요한 발화분석의 기준과 규준마련에 대한 단계 가 프로그램 개발과 지원 전에 우선적으로 선행되어야함을 강조하 였다. 또한 과학기술을 발화분석 프로그램 개발에 앞서 전사 프로 그램 개발에 적용하는 것이 적절한 순서라고 생각하였다.

- 사실 임상에서 오래 있다 보니까 그런 분석방법들에 대해서 많 이 잊고 있거든요? 그런 거에 대한 기초지식 부분들도 사실 재교 육이좀...(P8)

- 성인한테 왜 발화분석이 필요한지에 대한 강연이 진행됐으면 좋 겠어요…(P6)

- 컴퓨터에서 총 음절 수, 어절 수, 단어 수, 형태소 수 같은 것을 보 여주는 것도 중요하지만 부적절한 어휘같은 경우는 밑줄이 쳐져 
있다거나 아니면 문법적 오류 같은 경우도 문법 오류가 있는 경 우에 체크가 된다거나 그런 오류까지 체크가 될 수 있으면 좋을 것 같아요. (중략) 성인에서는 의미적으로 부적절한 어휘를 쓰는 지 아니면 조사도 쓰긴 쓰는데 문법 오류는 있는지와 같은 오류 들이요. 대신 아동 같은 경우는 오류 양상을 보는 것 보다는 이 아동이 이 표현을 쓰는지를 보는 용도가 조금 더 적합 할 것 같고 요. (P4)

- 클라우드화가 되어서 그 플랫폼을 바탕으로 많은 자료가 축적 이 될 수 있게 하면 더 좋을 거 같구요. (P6)

- 패드에서 어플같은 것도 어르신 분들이 좋아하시던데. 어플같은 것은 많이 만들 수도 있고요. SLP HOUSE에서 만들긴 하더라고 요. 저도 써보진 않았는데, 그런 것들 많이 활용하면 우리한테 더 좋을 것 같고, 환자들 치료할 때도 좀더 편하고 도움이 되고... 예 를 들면 동사치료 할 때 동사카드보다는 동사 동영상이 더 났더 라고요. (P1)

- 학자마다도 발화를 보는 관점에 따라 기준이 좀 달라서 다르게 분류하시는 경우가 있으시잖아요. 그래서 언어병리학의 개념에 서 일반적으로 좀 보편적으로 쓸 수 있는 분석 기준의 틀에 대해 그 전공분야의 대표적인 교수님들끼리 맞춰주시는 작업을 하는 게 기술 개발 전에 먼저 필요할 것 같아요. (P3)

- 해변가 같은 경우에는 그래도 그림을 보고 이야기하기 하는 것이 니까 $\cdots$ 그림을 설명할 때 반드시 나와야 하는 어휘가 있잖아요. 그럼 그 어휘가 있었는지 없었는지 정도는 체크가 되잖아요? 그 리고 그 그림이 좀 단순하고 한정적이기 때문에 사람들이 사용하 는 문장도 아주 많이 다르지는 않거든요. 그러니까 만약에 프로 그램을 개발을 한다고 하면, 일단 전사가 제대로 되는 거 가장 먼 저 만들고 그 다음에는 이제 간단한 그림, 해변가 이야기 같은 것 에 대한 자동 채점을 먼저 시도를 해보는 게 좋지 않을까... (P9) - 병원에서 구매를 해서 우리한테 주면 전사만 잘 되도 사용할 수 있을 것 같아요... (중략) 전사만 되면 분류나 분석 같은 경우는 우리가 할 수 있으니까 단순 전사만 되도 굉장히 도움이 될 것 같 아요. (P4)

한계점 인식 및 현실 순응

전략에 따른 세 번째 결과로 '한계점 인식 및 현실에 순응'이 관 찰되었다. 일부 참여자들의 경우에는 발화분석을 위한 임상적 활 용 환경이 제약되어 있고 의료 수가로 반영되지 않고 있어서 이러한 환경이 개선되지 않는다면 지금과 같이 여전히 제한적으로만 발화 분석을 시행할 수 밖에 없다고 반응하였다. 그리고 언어병리학 분 야에 과학기술을 적용하는 것에 대한 기대감 저하와 우려가 관찰
되었다. 특히 언어병리학 분야는 다른 보건재활 분야와 비교하여 현대 기술을 차용하는 측면이 더디며, 정확도와 신뢰도가 확보된 기술로 구현이 가능할지에 대하여 회의적이었고, 상용화되기까지 오랜 시간이 걸릴 것이라고 응답하였다. 또한 컴퓨터를 활용한 분 석 프로그램을 진단이나 중재에 활용하는 것에 대해 기타 전문가, 동료, 보호자가 부정적으로 바라보는 시선이 있어서 발화분석에 이를 활용하기는 쉽지 않을 것이라 지적하였다.

- 다른 병원과 비교했을 때 최대한 많이 발화를 분석하고 자세하 게 결과를 쓰고는 있는데, 이제 앞으로 급여기준체 개발계가 바 뀌잖아요? 급여화가 되면 심사원에서 정해놓은 기준에 따라 가 야되요. 그렇게 되면 아마 진짜 발화분석이 더 힘들어지지 않을 까... (P8)

- 저는 성인환자에게 관심이 많아요. 그런데 일단은 현실적으로 성 인에 대한 규준자료나, 연구 같은 게 선행이 돼서 좀 많아진다면 의미가 있어서 시간과 비용이 들더라도 발화분석을 할 의향은 있는데요. 근데 규준이 없고 지금과 같은 상황이라면 발화분석 을 많이 시행하지는 않을 것 같아요. (P5)

- 일단, 환자분들 중에 발음 쪽 문제도 같이 있어서, 말 명료도가 떨어지시는 분들도 있고 그러면 인식을 못할 것 같고, 예전에 음 성 인식해서 텍스트로 보여주는 거 있잖아요? 그거를 제가 다 수 정하려고 하면 그게 더 힘든 거에요. 그렇기 때문에 이게 과연 될 까 싶어요. (P9)

- 회의적인 거 같긴 해요. 내가 직접 갯수를 세는 거보다 프로그램 에서 발생하는 오류를 고치는 게 더 오래 걸리지 않을까 그런 걱 정이 되기도 하고 $\cdots$ 또 제가 지금까지 보아왔던 주제유지라던지 이런 부분은 컴퓨터가 분석해주기 어렵지 않을까 $\cdots$ (P6)

- 대규모 데이터가 없는 한 그게 실현 가능하지 않을 거라는 걸 알 고 있기 때문에 $\cdots(\mathrm{P} 7)$

- 아직은 이런 기술이 아주 뛰어나다고 생각이 안들거든요. 그러 면 실제로 이게 환자한테까지 적용이 되려고 하면 시간이 너무 오래 걸릴 것 같다라고 생각이 드는...(P5)

- 약간 새로운 거에 대해서 보수적인 느낌도 있고 해서 만약에 딱 나오는데 남들 아무도 사용 안하는데 나만 용감하게 쓰기가 좀… (중략) 언어는 사람 대 사람으로서 애기를 한다는 게 중요 하다는 인식이 있어서 조음치료하는 어플 같은 것도 요즘에 몇 개 나오고 있는데 왠지 그걸 들고 하고 있으면 보호자나 동료가 '저 치료사 되게 건성으로 한다'고 생각할까봐...(P6) 


\section{논의 및 결론}

본 연구는 성인언어장애 환자에서의 발화분석에 대한 경험 및 요구를 살펴보기 위하여 실태, 문제점, 문제점에 대한 극복방안을 확인하는 심층면담을 실시하고 근거이론 접근법으로 질적연구를 시행하였다. 이에, 연구결과 및 모형에서 관찰된 내용을 토대로 먼 저 중심현상인 성인언어장애 환자에서 발화분석을 적극적으로 시 행하지 못하도록 하는 것에 영향을 주는 인과적, 맥락적, 중재적 조 건 및 전략을 '성인 언어장애 대상의 발화분석 실태'의 측면에서 통 합적으로 논의하고, 그 다음으로는 모형의 결과 부분과 관련지어 참여자들의 필요와 요구를 반영한 "발화분석의 적용가능성을 확 대하기 위한 대안'을 모색해보고자 한다.

\section{성인언어장애 대상의 발화분석 실태}

임상현장에서 참여자들은 성인언어장애 환자의 평가 시에 공식 검사를 가장 널리 활용하고 있었으며 정해진 시간 내에 정해진 절 차에 따라 시행이 가능하고 수행력과 비교 가능한 규준을 제시한 다는 점에서 신뢰로운 검사라고 생각하고 있었다. 결과의 활용 측 면에서는 결과값이 점수화되어 제공되므로 의사나 다른 언어재활 사와의 의사소통이 원활하며 장애진단 상황과 같이 증빙이 필요한 경우에 객관적인 증거자료로 활용될 수 있다는 점을 장점으로 꼽 았다. 또한 비교적 짧은 시간 내에 다양한 언어양식(modality)의 능 력을 확인할 수 있어서 실어증 유형과 중증도를 판별하기에 적절하 다고 하였다. 성인언어장애 환자의 경우에는 정상적인 언어습득 이 후에 오는 병리적 손상으로 인하여 특정 언어기능의 결함이 생기 기 때문에 결함이 있는 부분을 파악하는데 있어 공식검사가 매우 유용하다(Kwon, 2007). 그러나 매우 경미한 능력의 저하를 보이는 경우에 공식검사 상으로는 정상범주에 포함되어 장애가 없다고 간 주되어 민감도에서의 제약이 발생할 수 있고(Kim, Shim, \& Yoon, 2019) 실제로 능력저하가 있는 환자를 점수에 근거하여 환자의 문 제점을 무시하게 될 가능성이 있다. 또한 공식 검사에서 제시하는 발화분석 기준(유창성 및 내용전달 측면)에 따라 특정 점수를 기 준으로 유창성/비유창성 실어증 유형으로 분류하거나 발화능력을 척도화하는 것은 실제 언어능력을 모두 반영하지 못하며 검사자의 경험과 주관적 의견이 개입될 수 있다는 점에서 그 문제점이 지적 되어 왔다(Shewan \& Donner, 1988). 장애 질환군 측면에서는 좌뇌 혈관성 손상이 아닌 우뇌손상이나 외상성 뇌손상, 치매와 같은 퇴 행성 질환의 경우에는 실어증 환자용 공식검사 항목으로는 파악하 기 어려운 언어의 화용적 측면의 기능저하를 확인하지 못하는 제 한점이 존재한다. 이를 보완하기 위하여 언어재활사들은 발화의
특성을 확인하는 발화분석 과정을 통해 공식 검사에서 파악할 수 없는 환자의 결함을 파악하고(Kwon et al., 1998) 치료 처방을 신청 하는 근거로도 활용할 수 있다. 또한 공식 검사의 종류가 한정적이 어서 발생할 수 있는 학습효과를 배제하는 동시에 중재상황에서 진전의 정도를 파악하는데 발화분석이 유용하므로 공식 검사 대 신 비공식적으로 발화분석을 실시하여 중재의 효과를 파악할 수 있다는 장점이 있다.

그러나 인터뷰 자료를 분석한 결과, 임상현장에서 세밀하고 정식 적인 수준에서의 전사와 발화분석을 시행하지 못하는 이유는 다 음의 네 가지로 종합되었다. 첫째, 발화분석을 위해 표준화된 수집 절차, 분석기준, 규준이 없어서 신뢰도가 저하되는 문제점을 지적 하였다. 절차와 기준이 없는 경우 그 결과를 믿기 힘들고, 특히나 발 화라는 것은 과제 유도절차에 따라 수행 양상이 달라질 수 있다 (Lundine \& McCauley, 2016). 또한 규준이 없으므로 결과 해석 시 참조할 만한 정보가 없어서 대상자의 수준이 어느 정도에 해당되 는 것인지, 경미한 정도로 수행력이 저하되는 경우 정상 및 비정상 여부를 판단하기 어렵다고 호소하였다. 그간 국외에서는 컴퓨터 기 반 언어분석 프로그램인 Systematic Analysis of Language Transcripts (SALT; Miller \& Iglesias, 2015)를 활용하여 수집한 아동 및 청소년기 연령대의 수 천개의 발화 자료에 근거하여 해당 연령대의 발화 규준을 정립하고 지속적으로 개정을 해오고 있다(Miller, Andriacchi, \& Nockerts, 2016). 그러나 우리나라 아동 연령대에서 는 학령 전기의 경우 $\mathrm{MLU}$ 기준이 있으나 대규모의 발화 자료에 근 거한 것이 아니며, 학령기의 경우에는 규준이 부족한 것이 지적되 었다(Oh, Yoon, \& Lee, 2020). 성인의 경우에는 국내외를 막론하고 그간 이루어졌던 연구들이 대부분 노화의 효과를 확인하기 위하 여 MLU, 구문복잡성, 절밀도(clausal density), 어휘의미능력 등의 특정 지표를 선택하여 연령에 따른 집단 간 비교(예, 청년 대 노년) 를 시행하는 방식으로 이루어졌기 때문에(Kemper \& Sumner, 2001; Nippold, Cramond \& Hayward-Mayhew, 2014; Lee et al., 2017; Yoon et al., 2018) 임상에서 활용할 수 있는 통합적인 규준 자 료는 부족한 실정이다.

둘째, 대부분의 참여자들은 아동 대상의 발화를 분석하는 교육 을 받은 경험에 비하여 성인 대상의 발화를 분석하는 방법에 대한 교육 경험이 매우 부족하였다. 이에 아동 대상으로 교육받은 언어 적 지표(의미, 구문, 형태, 음운)에 초점을 둔 발화분석 방법을 성인 대상자의 발화분석에 그대로 적용하게 되면서 발화분석의 실제 시 행과 의의의 가치가 충돌하였을 가능성이 있다. 아동은 일정한 발 달 단계에 따라 언어를 배워나가는 과정에서 각 발달 수준에 맞는 개개의 언어적 지표에 대한 분석을 통해 발화수준이 어떠한지를 확 
인하는 것이 중요하다. 또한 언어적 발달은 학습과정에도 영향을 미 치므로(McGee \& Richgels, 2000) 아동 대상자에게는 각 연령대를 대표하는 공통적인 언어적 지표를 확인하는 것이 중요할 수 있다. 그러나 성인의 경우에는 직업, 성격, 살아온 환경 등의 개인차가 발 화특성에 영향을 주는 부분이 크며, 노화나 병리로 인한 발화 능력 의 변화는 일정한 순서나 단계로 나타나는 것이 아니므로 각 연령 대에서 공통적으로 중요한 언어적 지표가 존재한다기보다는 각 개 인의 의학적 소견과 부합하는 특정 지표(전두엽 병리 환자의 경우 구문구조나 문법형태소)를 확인하는 것이 임상적 진단을 위해 더 적절할 수 있다. 또한 중재를 위한 목표선정을 할 때, 성인 대상자는 학습과의 관련성을 고려하여 발화의 완전한 회복을 우선순위로 고 려하기 보다는 대상자의 연령이나 상황에 따라 전반적인 의사소통 의 효율성 측면에 중재의 초점을 두는 경우가 많다(Simmons-Mackie, 2001). 이렇게 의사소통의 효율성 측면에서 발화분석에 접근하 는 경우 언어적 지표를 분석하는 것이 아니라 전반적인 발화의 양 상을 확인하는 것이 무엇보다 중요할 수 있다. 이러한 이유에서 아 동과 성인 대상자에게 요구되는 발화분석의 수준이나 정도는 다를 수 있고, 아동에게 적용되는 발화분석 방법을 그대로 적용하는 것 에 대한 임상적 유용성에서는 이견이 존재할 가능성이 있다.

셋째, 발화특성을 파악하기 위하여 전사와 분석을 시행하는 것 에는 많은 시간이 소요되므로 임상현장에서의 가장 큰 난관으로 작용한다는 견해가 지배적으로 관찰되었다. 또한 언어장애 환자의 경우 구문 구성의 결함과 신조어나 착어 등의 사용으로 발화의 내 용을 예측하기 어렵거나 말장애가 동반된 경우 전사의 정확도가 저하된다는 점을 호소하였다. 즉, 시간과 노력의 부담을 증가시킨 다는 부분이 발화분석이 가지는 가장 큰 제한점으로 나타났으며 이는 기존의 발화분석의 방법과 관련한 여러 문헌들(Kemp \& Klee, 1997; Baker, 1988; Pavelko, Jr Owens, Ireland, \& Hahs-Vaughn, 2016)에서 언급되어 오던 문제점으로서 재확인되었으며, 한국 아 동 언어장애 환자의 발화분석에 대한 언어재활사의 경험과 요구를 확인하는 연구(Oh et al., 2020)에서도 동일하게 나타난 결과로서 연령 및 대상자에 관계 없이 발화분석의 가장 큰 걸림돌로 확인되 었다. 이러한 어려움에 대한 하나의 대안으로 장노년층 경도인지장 애 환자를 대상으로 발화의 세밀한 정량적 측정과 평가를 대체할 수 있는 주관적 척도를 개발하고, 임상으로의 적용가능성을 탐색 한 연구(Kim et al., 2019)가 진행되었다. 이 선행연구에서는 훈련을 통해 언어재활사의 역량이나 경험을 통제한다는 조건 하에 3점 척 도를 활용하여 대상자의 발화의 질을 전반적으로 평가함으로써 시 간적으로 단축된 채점방식을 제안하기도 하였다.

넷째, 성인환자의 경우에는 대부분 뇌신경학적 손상으로 인해
병원으로 내원하게 되며, 의료적 진단의 절차 중 하나로서 언어검 사를 시행받기 때문에 진단명과 중증도를 빠른 시간 내에 확인하 는 것이 평가의 주 목적이 된다. 그리고 공식 검사에 비해 발화분석 의 필요성에 대한 의료전문가들의 이해도가 낮아 발화분석에 대한 의뢰나 처방이 이루어지지 않으며 처방코드도 존재하지 없는 실정 이다. 이에 발화검사는 의료수가로 반영되지 않으므로(발화검사 를 위한 시간이 보장되지 않음) 언어재활사가 이를 추가적으로 시 행할 경우 전체적인 평가나 치료 스케줄에 영향을 주는 애로사항 이 있었다. 결국 공식 검사를 통해 기본적인 언어적 진단명이나 중 증도가 파악되므로 기타 전문가는 발화분석의 시행이나 결과에 대 해 크게 관심이 없으며 결과지에 명시하더라도 이를 활용하여 의사 소통하는 경우가 없다고 보고하였다. 그리고 세밀한 환자의 특성을 파악하기 위해 언어재활사가 발화분석에 추가적으로 들이는 시간 과 노력에 비해 그 결과를 활용할 기회와 가치는 제한적이어서 발 화분석 시행에 대한 기회비용이 저하된다고 보았다. 위와 같은 애 로사항들로 인하여 성인언어장애 환자를 평가하는 대부분의 언어 재활사들은 발화분석의 중요성과 이점을 어느 정도 인식하면서도 이를 시행하지 못하거나 시행하더라도 공식 검사 내의 항목(K-WAB 의 스스로말하기)을 통해 유도되는 발화를 들으며 전반적으로 느 끼는 인상을 정해진 공식검사 시간 내에 실시간으로 빠르게 판단 하는 정도의 소극적인 발화분석을 시행하였을 것으로 생각된다.

\section{발화분석의 적용가능성을 확대하기 위한 대안}

발화분석의 적용가능성을 확대하기 위한 대안으로 제시된 참여 자들의 의견들은 다음의 두 가지로 종합되었다. 첫째, 참여자들은 '성인 발화분석의 기준과 규준 마련에 대한 요구'를 보였다. 참여자 들은 발화분석에 있어서 다양한 언어적 지표를 양적으로 분석해 주는 것도 중요하지만 질적인 측면에서의 오류, 특히 성인 대상자에 서 중요한 지표, 신경언어장애의 유형에 따른 주요 지표 등을 확인 하고 정립하는 것이 중요함을 주장하였다. 두 번째로는 '발화분석 과 관련된 다각적 측면의 지원에 대한 요구’가 나타났으며, 이를 위 하여 발화분석의 의의와 발화분석의 기초를 다루는 체계적인 교 육의 필요성, 보다 편리한 발화분석을 위하여 과학기술의 활용에 대한 견해를 피력하였다. 그 동안 국외에서는 Computerized Language Analysis (CLAN; MacWhinney, 2000), Computerized Profiling (Long \& Fey, 1988, 1989), Systematic Analysis of Language Transcripts (SALT; Miller \& Chapman, 2003)와 같은 다양한 컴퓨 터 자발화 분석 프로그램의 개발이 이루어졌고, 국내에서는 Korean Computerized Language Analysis (KCLA; Pae, Kim, Sung, \& Sung, 1998)와 Korean Language Analysis (KLA; Pae, Ha, \& So, 
2015) 등의 언어표본분석 프로그램이 소개되었다. 이러한 시도들 은 특히 최근 정보통신기술(information communication technology, ICT)의 발달에 힘입어 언어병리학 분야에도 ICT 기술을 적용 할 수 있는 가능성을 보여주었다. 또한 참여자들은 프로그램 개발 시에는 단계적으로 접근하는 것이 개발 및 실현 가능성을 높일 수 있다고 생각하면서 앞서 표준화된 공식 검사를 컴퓨터 프로그램 형식으로 개발하거나 발화 전사 프로그램을 먼저 개발한 후 발화 분석 프로그램의 순서로 개발하는 것을 제안하였다. 임상가의 수 기를 통한 전사와 컴퓨터를 활용한 자동전사의 정확도를 비교하는 연구(Busch, Sangen, Vanpoucke, \& Wieringen, 2017; Canault, le Normand, Foudil, Loundon, \& Hung, 2016; Oetting, Hartfield, \& Pruitt, 2009; Pae et al., 2016; Xu, Yapanel, \& Gray, 2009)는 발화분 석에 대한 요구뿐만 아니라 전사 작업 측면에도 자동화 등의 기술 활용에 대한 언어재활사의 관심을 반영한다.

그러나 일부 참여자들은 임상현장에서의 발화분석에 대한 ‘한계 점을 인식하고 현실에 순응하는' 양상도 보였다. 이러한 결과의 이유 로는 대부분의 성인 대상자들을 다루는 임상환경은 병원에 주로 국 한되어 있으므로 기타 전문가의 이해나 처방 없이는 이를 적극적으 로 시행하기 어렵다는 현실을 확인할 수 있었다. 이에 임상적 활용 환경 조성을 위해 기타 의료진들의 발화분석의 당위성에 대한 이해 와 발화분석에 대한 노력이 처방코드나 현실적인 의료수가로 반영 된다면 언어재활사들이 임상현장에서 발화분석을 보다 적극적으 로 시행하는데 도움을 줄 수 있을 것으로 생각된다. 그리고 ICT기 술을 프로그램 개발에 적용하고 실현하는 것이 가능할지에 관한 불 신도 관찰되었다. 참여자들은 기존의 컴퓨터 발화분석 프로그램의 사용성 측면에서의 문제점들을 지적하면서 다음과 같은 부정적 견 해를 보이기도 하였다. "사실 컴퓨터 프로그램을 활용하려면 지금 들이는 시간과 비용보다 확 줄어야 사용할 수 있을 것 같거든요. 그 런데 기존과 똑같다거나 오히려 이중으로 노력이 필요하다 그러면 사용하기 싫고요. 자동전사가 정확하게 되어야 하고요. 가능한 많 은 언어적 지표를 분석해주면 좋고요. 그리고 최소한의 클릭으로 분석이 이루어진 후 결과까지 나오는 거 있잖아요. 클릭했는데 어느 수준에 해당된다라는 결과가 딱 나와야 $\cdots$ (P5)." 또한 발화분석에 서 언어재활사의 역할과 가치에 대하여 다음과 같은 의견들도 있었 다. "화용적인 부분은 사람과의 상호작용이 더 중요하니까 언어재 활사가 인터뷰한다면 분석과 해석도 우리가 하는 것이 더 적절한 것 같아요 (P8)." "언어병리학 쪽은 질적인 측면의 분석이 중요하잖아 요? 사실 수량화하는 거는 컴퓨터로 할 수 있겠지만 그 안에 내재된 질적인 내용을 분석하는 거는 아직은 경험이 좀 있고 이런 전문가 들이 해야지 더 정확하게 나올 수 있다고 보거든요 (P9).” 이러한 의
견들은 추후 발화분석 분야에 새로운 과학기술을 개발하고 적용할 때 참고해야 할 부분이 되며, 언어재활사의 요구와 수요가 어디에 초 점을 두고 있는지를 확인시켜준다는 측면에서 중요하다. 마지막으 로 언어병리학 분야는 다른 재활이나 보건관련 분야에서 컴퓨터 기 반 프로그램을 개발 및 활용하는 활동에 비해 현대기술을 적극적 으로 차용하는 측면이 더딤이 참여자들에 의하여 지적되었다. 이러 한 이면에는 진단과 중재를 위한 아날로그적 활동이 디지털을 활용 한 작업보다 신뢰롭고 우위에 있으며 언어재활사로서의 직업적 사 명을 다하는 것이라는 인식도 존재함을 확인하였다. 따라서 임상현 장에서의 발화분석의 효용성을 높이고 실현 가능성을 견고히 하기 위하여 ICT 기술의 개발과 활용도 중요하지만 새로운 기술의 적용 과 습득에 대한 언어재활사의 인식도 유연하게 개선되어야 할 필요 가 있음을 보여준다.

\section{결론}

본 연구는 실제 임상현장에서 언어재활사가 성인 대상자의 발화 분석을 시행하면서 겪는 어려움과 그 어려움을 유발하는 요인, 요 구 등을 근거 이론을 통해 상세히 들여다봄으로써 성인 발화분석 의 실태를 확인하고 요구를 반영하는 극복 방안을 제안하였다는 데 그 의의가 있다. 발화분석은 언어발달을 파악하는 주된 분석 방 법이지만 자료를 전사하고 분석하는데 시간이 많이 소요되고 검사 자 간의 신뢰도를 확보하기 어려운 점 등이 임상에서의 애로사항으 로 존재한다. 그리고 후천적 병리로 인한 성인언어장애 환자 사례 에서는 많은 경우에 언어장애의 특성이 공식 검사를 통한 언어의 하위 영역에서 일차적으로 드러날 수 있다. 또한 성인은 아동 집단 에 비하여 발달을 보여주는 연령 별 발화 지표나 특성에 대한 자료 가 부족하고 그 규준도 아동에 비하여 미비한 실정이므로 성인 발 화분석의 임상적 의의와 현실적 어려움으로 인한 기회비용 사이에 서 우리 언어재활사의 결정과 시행을 더욱 어렵게 만든다. 따라서 인터뷰를 통해 수집된 임상현장의 수요와 요구를 반영할 수 있다 면 언어재활사의 수고와 염려를 덜어주면서 추가적인 언어검사로 서 발화분석의 가치와 역할이 보장될 수 있음을 확인하였다. 추가 적으로는 개선방안의 하나로써 발화분석의 편리성과 객관성을 확 보하기 위해 과학기술을 활용한 자동화된 발화분석 시스템 개발 과 플랫폼 구축에 대한 요구도 확인되었다. 이렇게 기술개발을 통 해 대규모 성인 집단을 대상으로 언어 영역 전반에 걸친 빅데이터 연구가 가능하다면 축척된 자료를 통해 대표성이 확보된 규준을 제공할 수 있고 성인의 발화 특성에 대한 기초자료로써 활용될 것 이며 나아가 한국형 성인기 언어발달 모형을 수립하는 토대가 될 수 있겠다. 
Ji Hye Yoon, et al. • A qualitative Study on Experiences of Language Sample Analysis for Adults

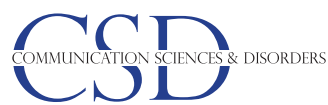

\section{REFERENCES}

Baker, L. (1988). The use of language sample analysis- results of questionnaire. Bulletin of the College of Speech Therapists, 2-4.

Busch, T., Sangen, A., Vanpoucke, F., \& Wieringen, A. van. (2017). Correlation and agreement between Language ENvironment Analysis (lenaTM) and manual transcription for Dutch natural language recordings. Behavior research methods, 50(5), 1921-1932.

Canault, M., le Normand, M. T., Foudil, S., Loundon, N., \& Hung, T. V. (2016). Reliability of the language environment analysis system (lena (tm)) in European French. Behavior Research Methods, 48(3), 1109-1124.

Choi, H. (2015). Ratio of correct information unit and cognitive functions in healthy elderly adults. Communication Sciences \& Disorders, 20(3), 435445.

Edmondson, A. C., \& McManus, S. E. (2007). Methodological fit in management filed research. Academy of Management Review, 32(4), 1155-1179.

Finestack, L. H., Rohwer, B., Hilliard, L., \& Abbeduto, L. (2020). Using computerized language analysis to evaluate grammatical skills. Language, Speech, and Hearing Services in Schools, 51(2), 184-204.

Godefroy, O., Bubois, C., Debachy, B., Leclerc, M., \& Kreisler, A. (2002). Vascular aphasias: main characteristics of patients hospitalized in acute stroke units. Stroke, 33(3), 702-705.

Han, W., \& Yim, D. (2016). Relationship among complex sentence production, implicit learning, and working memory based on structural priming method in children with specific language impairment. Communication Sciences \& Disorder, 21(4), 590-604.

Hatch, J. A. (2002). Doing qualitative research in education settings. albany, NY: State University of New York Press.

Hwang, Y. M., Park, H. R., \& Kim, S. H. (2019). A qualitative study on the assessment and intervention of literacy for children with language learning disabilities by speech-language pathologists. Communication Sciences \& Disorders, 24(2), 416-431.

Im, E. J., Kwon, M., \& Shim, H. S. (2001). The informativeness and efficiency of the connected speech samples in Korean fluent aphasics. Korean Journal of Communication \& Disorders, 6(2), 374-391.

Jin, C., Choi, H., \& Lee, J. Y. (2016). Usefulness of spontaneous speech analysis scales in patients with mild cognitive impairment and dementia of $\mathrm{Al}$ zheimer's type. Communication Sciences \& Disorders, 21(2), 284-294.

Kemp, K., \& Klee, T. (1997). Clinical language sampling practices: results of a survey of speech-language pathologists in the United States. Child Lan- guage Teaching \& Therapy, 13(2), 161-176.

Kemper, S., \& Sumner, A. (2001). The structure of verbal abilities in young and older adults. Psychology and Aging, 16(2), 312-322.

Kim, H., Heo, J. H., Kim, D. Y., \& Kim, J. W. (2009). Screening test for aphasia and neurologic-communication disorders (STAND). Seoul: Hakjisa.

Kim, H., \& Na, D. L. (1997). Korean-Boston Naming Test (K-BNT). Seoul: Hakjisa.

Kim, H., \& Na, D. L. (2012). Paradise-Korean version of Western Aphasia Battery-Revised (PK-WAB-R). Seoul: Paradise Welfare Foundation.

Kim, J., Shim, J., \& Yoon, J. H. (2019). Subjective rating scale for discourse: evidence from the efficacy of subjective rating scale in amnestic mild cognitive impairments. Medicine, 98(2), e14041.

Kim, S. M., \& Lee, E. J. (2013). A qualitative study on teachers' perceptions and response processes towards preschool children who stutter. Communication Sciences \& Disorders, 18(2), 203-222.

Kwon, H. (2016). Understanding grounded theory. Korean Policy Sciences Review, 20(2), 181-216.

Kwon, M. (2007). A qualitative study of an assessment model for neurogenic speech-language disorders. Korean Journal of Communication \& Disorders, 12(1), 52-76.

Kwon, M., Kim, H., Choi, S., Na, D. L., \& Lee, K. (1998). A study for analyzing spontaneous speech of Korean adults with CIU scoring system. Korean Journal of Communication \& Disorders, 3(1), 35-49.

Lee, Y., Choi, J., Yoon, J. H., Kim, Y. S., Min, J. S., \& Kim, J. (2017). Lifespan development of word use from early childhood to old age. Communication Sciences \& Disorders, 22(4), 717-729.

Long, S. H., \& Fey, M. E. (1988). Computerized Profiling Version 6.2 (Apple II series) [Computer program]. Ithaca, NY: Ithaca College.

Long, S. H., \& Fey, M. E. (1989). Computerized Profiling Version 6.2 (Macintosh and MS-DOS series) [Computer program]. Ithaca, NY: Ithaca College.

Lundine, J. P., \& McCauley, R. J. (2016). A tutorial on expository discourse: structure, development, and disorders in children and adolescents. American Journal of Speech-Language Pathology, 25(3), 306-320.

MacWhinney, B. (2000). The CHILDES project: Tools for analyzing talk (3rd ed.). Mahwah, NJ: Erlbaum.

McGee, L. M., \& Richgels, D. J. (2000). Literacy's beginnings: supporting young readers and writers (M. S. Kim \& Y. R. Shin, Trans.). Seoul: Hakjisa.

Miller, J., Andriacchi, K., \& Nockerts, A. (2016). Assessing language production using SALT software: a clinician's guide to language sample analysis (2nd ed.). Madison, WI: SALT Software. 
Miller, J., \& Chapman, R. S. (2003). SALT for Windows, Version 6.1 [Computer program]. Muscoda, WI: SALT Software, LLC.

Miller, J., \& Iglesias, A. (2015). Systematic Analysis of Language Transcripts (SALT), Version 16 [Computer software]. SALT Software, LLC.

Ministry of the Interior and Safety. (2019). Health Statistics. Sejong: Author.

Nippold, M. A., Cramond, P. M., \& Hayward-Mayhew, C. (2014) Spoken language production in adults: examining age-related differences in syntactic complexity. Clinical Linguistics and Phonetics, 28(3), 195-207.

Oetting, J. B., Hartfield, L. R., \& Pruitt, S. L. (2009). Exploring LENA as a tool for researchers and clinicians. ASHA Leader, 14(6), 20.

Oh, S. J., Yoon, J. H., \& Lee, Y. (2020). A qualitative study on experiences and needs of language analysis by speech-language pathologists: focused on children with language disorders. Communication \& Science Disorders, 25(2),169-189.

Pae, S., Kim, K., Sung, K., \& Sung, J. (1998). Korean Computerized Language Analysis 1.0. Korean Journal of Communication \& Disorders, 3, 123-137.

Pae, S., Ha, S., So, J. (2015). Korean Language Analysis. kla.halllym.ac.kr

Pae, S., Yoon, H., Seol, A., Gilkerson, J., Richards, J. A., Ma, L., \& Topping, K. (2016). Effects of feedback on parent-child language with infants and toddlers in Korea. First Language, 36(6), 549-569.

Park, H. S. (2006). Korean Test for Differential Diagnosis of Aphasia. Seoul: Yonsei University Press.

Paul, R., \& Norbury, C. (2012). Language disorders from infancy through adolescence (4th ed.). St. Louis, MO: Mosby.

Pavelko, S. L., Owens Jr, R. E., Ireland, M., \& Hahs-Vaughn, D. L. (2016). Use of language sample analysis by school-based SLPs: results of a nationwide survey. Language, Speech, and Hearing Services in Schools, 47(3), 246-258.

Pyun, S. B. (2008). Korean version of Frenchay Aphasia Screening Test. Seoul: Hanmi.

Shewan, C. M., \& Donner, A. P. (1988). A comparison of three methods to evaluate change in the spontaneous language of aphasic individuals. Journal of Communication Disorders, 21(2), 171-176.

Simmons-Mackie, N. (2001). Social approaches to aphasia intervention. In Chapey R (Ed.), Language intervention strategies in aphasia and related neurogenic communication disorders (4th ed.) (pp. 246-268). Philadelphia, Lippincott, Williams \& Wilkins.

Strauss, A. (1987). Qualitative analysis for social scientists. Cambridge: Cambridge University Press.

Strauss, A., \& Corbin, J. (1990). Basics of qualitative research: grounded theory procedures and techniques. Newbury Park, CA: Sage Publications.

Vreede, G. J. D., Jones, N., \& Mgaya, R. J. (1998). Exploring the application and acceptance of group support systems in Africa. Journal of Management Information Systems, 15(3), 197-234.

Xu, D., Yapanel, U., \& Gray, S. (2009). Reliability of the LENA Language Environment Analysis system in young children's natural home environment. (Technical Report LTR-05-2). Retrieved from: http://www.lenafoundation.org/ TechReport.aspx/Reliability/LTR-05-2.

Yoon, J. H., Jeong, H. Y., Lee, Y., Kim, Y. S., Choi, J., \& Kim, J. (2018). Lifespan development of syntactic ability from early childhood to old age. Communication Sciences \& Disorders, 23(4), 929-946. 
Appendix 1. 후천성 신경언어장애 환자 대상의 발화분석에 대한 개념의 범주화

\begin{tabular}{|c|c|c|}
\hline 개념 & 하위범주 & 범주 \\
\hline 성인언어장애를 위한 검사종류가 적어서 학습효과가 있을 수 있음 & \multirow{4}{*}{ 공식검사의 맹점이 존재함 } & \multirow{22}{*}{$\begin{array}{c}\text { 발화분석의 강점과 제한점이 } \\
\text { 공존 }\end{array}$} \\
\hline 주관적으로 평가하는 항목(K-WAB의 스스로말하기 영역)에서 신뢰도 문제가 발생할 수 있음 & & \\
\hline 미세한 능력의 저하를 탐지하지 못함(매우 경도의 중증도를 보이는 환자는 정상으로 판단될 수 있음) & & \\
\hline 점수 상 실어증 유형 분류 기준에 부합하지 않는 환자에 대한 정보가 부족함 & & \\
\hline 인지능력을 반영함 & \multirow{8}{*}{$\begin{array}{c}\text { 진단상황에서 발화분석이 } \\
\text { 도움을 줌 }\end{array}$} & \\
\hline 화용능력을 확인하는데 도움됨 & & \\
\hline 공식검사의 단점을 보완함 & & \\
\hline 가장 자연스러운 실생활의 표현을 반영함 & & \\
\hline 중재 목표 선정에 도움을 줌 & & \\
\hline 중재 효과 확인에 유용함 & & \\
\hline 중증도가 경한 환자의 문제 확인에 용이함 & & \\
\hline 장애진단이나 치료처방을 위한 보충 증빙자료가 됨 & & \\
\hline 실시요강이 제공되어 편리함 & \multirow{10}{*}{$\begin{array}{c}\text { 진단평가의 목적으로는 } \\
\text { 공식검사가 가장 } \\
\text { 효율적이라 생각함 }\end{array}$} & \\
\hline 수행력과 비교가능한 규준을 제시함 & & \\
\hline 실어증 유형과 중증도를 확인할 수 있음 & & \\
\hline 장애진단의 주요 근거자료가 됨 & & \\
\hline 기타 전문가들과의 의사소통에 도움이 됨 & & \\
\hline 보호자와의 상담 시에 절대적인 점수나 위치를 제공할 수 있어서 의사소통에 용이함 & & \\
\hline 각 지표가 평소 언어능력을 반영하지 못함 & & \\
\hline 발화분석의 신뢰도 및 정확도 저하됨 & & \\
\hline 비교규준이 없으므로 해석이 어려움 & & \\
\hline 평가자 간 신뢰도 저하됨 & & \\
\hline 아동의 경우 발화분석의 과정을 자세하게 배우고 실습함. & \multirow{2}{*}{-} & \multirow{2}{*}{$\begin{array}{c}\text { 성인 발화분석에 대한 교육 } \\
\text { 및 경험의 부족 }\end{array}$} \\
\hline 성인의 경우 발화분석의 과정을 제대로 배운 적이 없음 & & \\
\hline 전사 시간이 오래걸림 & \multirow{2}{*}{$\begin{array}{c}\text { 발화전사 및 분석에는 시간과 } \\
\text { 노력이 많이 듦 }\end{array}$} & \multirow{4}{*}{$\begin{array}{c}\text { 발화분석의 시행과 관련된 } \\
\text { 어려움 }\end{array}$} \\
\hline 분석 시간이 오래걸림 & & \\
\hline 말(speech)측면에서 말속도나 발음에따라 전사 정확도 확보 어려움 & \multirow{2}{*}{$\begin{array}{c}\text { 전사의 정확성에 대한 } \\
\text { 신뢰도 부족함 }\end{array}$} & \\
\hline 맥락이 없는 발화는 전사가 어려움 & & \\
\hline 발화는 가장 자연스러운 언어임 & \multirow{2}{*}{$\begin{array}{c}\text { 발화분석의 중요성을 } \\
\text { 알고 있음 }\end{array}$} & \multirow{3}{*}{$\begin{array}{c}\text { 발화분석의 중요성은 인식하 } \\
\text { 지만 임상현장에서 적극적으 } \\
\text { 로 시행하지 못함 }\end{array}$} \\
\hline 발화분석을 통해 치료의 문제점을 찾을 수 있음 & & \\
\hline 표준화된 검사들을 우선 시행 & - & \\
\hline 수가로 반영되지 않음 & \multirow[t]{2}{*}{-} & \multirow{2}{*}{ 열악한 임상환경 } \\
\hline 발화분석에 대한 처방코드가 없음 & & \\
\hline 임상적 가치가 공식검사에 비해 크지 않음 & \multirow{3}{*}{ 발화분석의 활용에 대한 견해 } & \multirow{6}{*}{$\begin{array}{c}\text { 발화분석 결과의 활용도가 } \\
\text { 저하됨 }\end{array}$} \\
\hline 결과지에 간단히만 명시함 & & \\
\hline 임상가 본인 스스로 참조하는 정도로만 활용함 & & \\
\hline 기타 전문가들과의 이해도나 관심이 낮음 & \multirow{3}{*}{$\begin{array}{c}\text { 타인과의 의사소통상황에서 } \\
\text { 발화분석결과의 가치 }\end{array}$} & \\
\hline 기타 전문가들과 결과에 대해 의사소통하지 않음 & & \\
\hline 환자 및 보호자 상담 시에 약간 활용함 & & \\
\hline
\end{tabular}


Appendix 1. Continued

\begin{tabular}{|c|c|c|}
\hline 개념 & 하위범주 & 범주 \\
\hline 말을 잘하는 환자는 치료실에 오지 않음 & \multirow{2}{*}{$\begin{array}{l}\text { 발화분석을 시행할 수가 없는 } \\
\text { 경우가 존재함 }\end{array}$} & \multirow{4}{*}{$\begin{array}{l}\text { 성인대상자에서 발화분석의 } \\
\text { 가치에 대한 견해 차이 }\end{array}$} \\
\hline 실어증이 심한 경우 발화분석을 할 수가 없음 & & \\
\hline 성인에게 있어 언어적 지표의 의미가 크지 않음 & \multirow{2}{*}{$\begin{array}{l}\text { 발화분석의 효용성에 대한 } \\
\text { 의문이 있음 }\end{array}$} & \\
\hline 정상 노화로 인한 감퇴인지 병리로 인한 감퇴인지 감별 어려움 & & \\
\hline 기존 컴퓨터 발화분석 프로그램에 대해 들어본 적 없음 & \multirow{3}{*}{$\begin{array}{l}\text { 기존의 다양한 기술에 대한 } \\
\text { 관련 지식 및 경험 부족 }\end{array}$} & \multirow{8}{*}{$\begin{array}{l}\text { 발화분석과 관련된 다양한 } \\
\text { 기술활용에 대한 인식 차이 }\end{array}$} \\
\hline 기존 컴퓨터 발화분석 프로그램에 대해 들어본적은 있으나 관심이 없어서 활용해본 적 없음 & & \\
\hline $\begin{array}{l}\text { 기존 컴퓨터 발화분석 프로그램을 활용하려고 시도하였으나 효율성 측면이 저하되어 더 이상 } \\
\text { 활용하지 않음 }\end{array}$ & & \\
\hline 사용방법이 복잡하고 불편하다고 들음 & \multirow{5}{*}{$\begin{array}{l}\text { 기존의 다양한 기술활용에 } \\
\text { 대한부정적 인식 }\end{array}$} & \\
\hline 편리성 측면에서 수기로 하는 것과 크게 차이가 없음 & & \\
\hline 오류가 많이 발생함 & & \\
\hline 연구목적으로만 활용하는 것이 좋겠음 & & \\
\hline 신뢰도에 대한 믿음이 없음 & & \\
\hline 공식검사 항목을 시행하고 전반적인 발화특성에 대한 소견을 확인함 & - & $\begin{array}{c}\text { 공식검사를 통해 수집된 발화 } \\
\text { 를 약식으로 분석함 }\end{array}$ \\
\hline 공식검사점수 산정을 위한 채점만을 시행함 & - & $\begin{array}{l}\text { 발화분석을 따로 } \\
\text { 시행하지 않음 }\end{array}$ \\
\hline 외상성뇌손상,우반구손상, 치매환자에게 다양한 과제를 시행하고 화용적 측면에서 분석함 & - & $\begin{array}{l}\text { 경우에 따라 추가적으로 } \\
\text { 발화분석 시행함 }\end{array}$ \\
\hline 문법형태소 사용능력이 중요함 & \multirow{4}{*}{$\begin{array}{l}\text { 성인에 대한 주요 발화분석 } \\
\text { 지표 기준 정립 }\end{array}$} & \multirow{14}{*}{$\begin{array}{l}\text { 성인 발화분석의 기준과 } \\
\text { 규준 마련에 대한 요구 }\end{array}$} \\
\hline 문장 구성 여부, 최대문장길이가 중요함 & & \\
\hline 단어개수, 어휘다양도가 중요함 & & \\
\hline 내용의 적절성, 주제유지능력이 중요함 & & \\
\hline 정상인 발화를 통해 규준 만들어야 함 & \multirow{2}{*}{$\begin{array}{l}\text { 성인에 대한 주요 발화분석 } \\
\text { 지표 규준 정립 }\end{array}$} & \\
\hline 성인 대상의 다양한 발화 특성 연구가 필요함 & & \\
\hline 문장구성 요소, 평균 및 최대 문장 길이가 중요함 & \multirow{4}{*}{$\begin{array}{c}\text { 아동에 대한 주요 발화분석 } \\
\text { 지표 }\end{array}$} & \\
\hline 형태소 개수가 중요함 & & \\
\hline 단어개수, 어휘다양도, 새로운 단어 출현여부가 중요함 & & \\
\hline 화용적 측면의 지표가 중요함 & & \\
\hline 성인에서의 발화는 개인차나 환경의 영향이 큼 & \multirow{4}{*}{$\begin{array}{c}\text { 연령 집단에 따른 발화의 } \\
\text { 임상적 가치에 대한 } \\
\text { 입장 차이 }\end{array}$} & \\
\hline 성인에서의 발화능력은 의사소통의 효율성 측면에서 판단해야함 & & \\
\hline 아동에서 발화는 발달수준을 반영함 & & \\
\hline 아동에서의 발화능력은 학습에 영향을 미침 & & \\
\hline 발화분석의 의의 소개 & \multirow{2}{*}{$\begin{array}{c}\text { 발화분석의 기초에 대한 } \\
\text { 체계적 재교육 제공 }\end{array}$} & \multirow{6}{*}{$\begin{array}{l}\text { 발화분석과 관련된 다각적 } \\
\text { 측면의 지원에 대한 요구 }\end{array}$} \\
\hline 언어학적 분석지표의 정의 소개 & & \\
\hline 전사 및 분석의 정확성 확보 & \multirow{4}{*}{ 새로운 기술에 대한 요구사항 } & \\
\hline 전사 및 분석의 자동성(편리성) 확보 & & \\
\hline 의미, 구문, 형태, 음운, 화용 측면에서 가능한한 많은 지표를 분석해줄 것 & & \\
\hline 유도절차나 과제 제공해줄 것 & & \\
\hline
\end{tabular}

(Continued to the next page) 
Appendix 1. Continued

\begin{tabular}{|c|c|c|}
\hline 개념 & 하위범주 & 범주 \\
\hline \multicolumn{3}{|l|}{ 언어학적 지표에 대한 양적인 측정뿐만 아니라 질적인 측면의 오류를 판단해줄 것 } \\
\hline \multicolumn{3}{|l|}{ 규준을 제공할 것 } \\
\hline \multicolumn{3}{|l|}{ 간단하고 직관적인 형태의 인터페이스 제공할 것 } \\
\hline \multicolumn{3}{|l|}{ 최적화된 사용환경(설치 권장사양)에 대한 정보 제공할 것 } \\
\hline \multicolumn{3}{|l|}{ 결과지의 형태로 출력되길 바람 } \\
\hline \multicolumn{3}{|l|}{ 무료로 사용할 수 있는 프로그램으로 개발되길 바람 } \\
\hline \multicolumn{3}{|l|}{ 컴퓨터가 아닌 이동형 장치(핸드폰, 테블릿)등에서도 구현되길 바람 } \\
\hline \multicolumn{3}{|l|}{ 클라우드화되어 빅데이터로 활용할 수 있길 바람 } \\
\hline \multicolumn{3}{|l|}{ 즉각적인 피드백 반영을 통해 업데이트 되길 바람 } \\
\hline 장노년층도 어플 등의 프로그램 활용하는 것을 선호함 & \multirow{2}{*}{$\begin{array}{l}\text { 새로운 기술 활용에 대한 } \\
\text { 긍정적 태도 및 기대감 }\end{array}$} & \\
\hline 언어병리학 분야에도 현대 기술을 적용하여 자동화된 발화분석 가능하다고 생각함 & & \\
\hline 표준화공식검사의 시행 및 채점 절차가 컴퓨터 프로그램형식으로 자동화되는 것이 먼저라고 생각함 & \multirow[b]{2}{*}{ 기술개발에 대한 순서 } & \\
\hline $\begin{array}{l}\text { 자동화된 발화 전사 프로그램이 먼저 개발된 후에 자동화된 발화 분석 프로그램이 개발되는 것이 } \\
\text { 적절하다고 생각함 }\end{array}$ & & \\
\hline 급여체계 기준변화에 따라 시행이 어려울 것으로 예상함 & \multirow{2}{*}{$\begin{array}{l}\text { 임상 활용환경에 대한 } \\
\text { 제약이 여전히 존재할 } \\
\text { 것으로 예상함 }\end{array}$} & \multirow{10}{*}{ 한계점 인식 및 현실 순응 } \\
\hline 규준들이 마련되지 않는다면 시행하지 않을 예정임 & & \\
\hline 앞으로도 발화분석을 위한 처방은 없을 것으로 예상함 & \multirow{2}{*}{$\begin{array}{c}\text { 발화 분석에 대한 의료수가 } \\
\text { 산정이 여전히 어려울 } \\
\text { 것으로 예상함 }\end{array}$} & \\
\hline 전사와 분석 과정에 대한 노력이 현실적인 의료수가로 반영되지 않는다면 시행하지 않을 예정임 & & \\
\hline 언어병리학 분야는 현대 기술을 활용하는 측면이 더딤 & \multirow{4}{*}{$\begin{array}{l}\text { 새로운 기술 활용에 관한 } \\
\text { 기대감 저하 및 우려 }\end{array}$} & \\
\hline 정확도와 신뢰도가 확보된 프로그램으로 실현이 가능할지에 대해 회의적임 & & \\
\hline 언어는 질적인 측면이 중요하므로 기계활용보다는 전체적인 전문가가 직접 하는 것이 더 적절함 & & \\
\hline 상용화되기까지 시간이 매우 오래걸릴것 같음 & & \\
\hline 컴퓨터 프로그램을 진단이나 중재에 활용하는 것을 동료들이 부정적으로 보는 경우가 있음 & \multirow{2}{*}{$\begin{array}{l}\text { 기술활용에 대한 주변의 } \\
\text { 부정적 인식이 존재함 }\end{array}$} & \\
\hline 보호자들이 새로운 기술활용에 대해신뢰하지 못하거나 인정하지 않는 경우가 있음 & & \\
\hline
\end{tabular}




\section{국문초록}

\section{언어재활사의 언어표본분석 경험 및 요구에 관한 질적연구: 후천성 신경언어장애를 중심으로 윤지혜' · 오소정' · 이윤경1}

1한림대학교 언어청각학부, 2동명대학교 언어치료청각학과

배경 및 목적: 본 연구는 근거이론에 기반한 질적연구방법을 통해 임상이나 교육현장에서 이루어지는 후천성 신경언어장애 환자의 언 어표본분석에 대한 전문가의 견해를 살펴보는 것에 목적이 있다. 방법: 후천성 신경언어장애 환자를 평가하고 치료해 본 경험이 있는 10 인의 언어재활사를 대상으로 심층면담을 실시하고 개방코딩, 측코딩, 선택코딩의 절차에 따라 자료를 분석하였다. 결과: 축코딩 과정 을 통해서 ‘발화분석의 중요성은 인식하지만 임상현장에서 적극적으로 시행하지 못함’이 중심현상으로 관찰되었다. 이러한 중심현상 에 영향을 미치는 인과적 조건으로는 ‘발화분석의 강점과 제한점이 존재', '성인 발화분석에 대한 교욱 및 경험의 부족, '발화분석의 시 행과 관련된 어려움’이 작용하였다. 맥락적 조건은 ‘열악한 임상환경'과 ‘발화분석 결과의 활용도 저하’으로 나타났다. 중심현상에 대처 하는 작용/상호작용 전략으로는 '공식검사를 통해 수집된 발화를 약식으로 분석함', '발화분석을 따로 시행하지 않음, '경우에 따라추 가적으로 발화분석 시행함'이었으며 이에 영향을 미치는 중재적 조건으로 '성인대상자에서 발화분석의 가치에 대한 견해 차이', '발화 분석과 관련된 다양한 기술활용에 대한 경험과 인식 차이'가 작용하였다. 중심현상에 대한 결과는 '성인 발화분석 기준과 규준 마련에 대한 요구', '발화분석과 관련된 다각적 측면의 지원에 대한 요구' '한계점 인식 및 현실 순응'으로 나타났다. 논의 및 결론: 본 연구에서 는 실제 임상현장에서 언어재활사가 성인 대상자의 발화분석을 시행하면서 겪는 어려움과 그 어려움을 유발하는 요인, 극복 방안 등을 근거 이론을 통해 상세히 들여다봄으로써 발화분석의 실태를 확인하고 대안을 통해 그 가치를 확보하는 방법을 제안하였다.

핵심어: 성인, 신경언어장애, 질적연구, 근거이론

이 논문은 2019년 대한민국 교육부와 한국연구재단의 지원을 받아 수행된 연구임(NRF-2019S1A5A2A03052093).

이 논문은 2020년도 한림대학교 교비연구비에 의하여 연구되었음(No. HRF-202003-009).

\section{참고문헌}

권미선(2007). 신경말언어장애 진단모델에 관한 질적 연구. 언어청각장애연구, 12(1), 52-76.

권미선, 김향희, 최상숙, 나덕렬, 이광호(1998). 한국성인의 자발화 분석에 관한 연구: CIU분석을 중심으로. 언어청각장애연구, 3(1), 35-49. 권향원(2016). 근거이론의 수행방법에 대한 이해. 한국정책과학학회보, 20(2), 181-216.

김승미, 이은주(2013). 취학 전 말더듬아동 교사의 인식과 반응과정에 관한 질적 연구. 언어청각장애연구, 18(2), 203-222.

김향희, 나덕렬(1997). 한국판 보스톤 이름대기 검사. 서울: 학지사.

김향희, 나덕렬(2012). 한국판 웨스턴 실어증 검사(Korean version of Western Aphasia Battery, K-WAB). 서울: 파라다이스복지재단.

김향희, 허지회, 김덕용, 김정완(2009). 실어증-신경언어장애 선별검사(Screening Test for Aphasia and Neurologic-communication Disorders,

STAND). 서울: 학지사

박혜숙(2006). 한국 실어증 감별진단검사(Korean Test for Differential Diagnosis of Aphasia, KTDDA). 서울: 연세대학교 출판부.

배소영, 김광선, 성경훈, 성진아(1998). 컴퓨터와 언어능력 진단평가 (Korean Computerized Language Analysis 1.0). 언어청각장애연구, 3, 123-137. 배소영, 하승희, 소정민(2015) 한국어 발화분석(Korean Language Analysis). kla.halllym.ac.kr.

보건복지부(2009). 보건복지부 건강통계.세종: 보건복지부.

윤지혜, 정혜영, 이윤경, 김유섭, 최지은, 김지수(2018). 초기아동기(유아기)에서 노년기까지 전생애 구문 능력 발달: 대화 자료 분석을 중심으로.

Communication Sciences \& Disorders, 23(4), 929-946.

이윤경, 최지은, 윤지혜, 김유섭, 민준상, 김지수(2017). 초기 아동기(유아기)에서 노년기까지 전생애 어휘 사용 발달: 대화 자료 분석을 중심으로. 


\section{Communication Sciences \& Disorders, 22(4), 717-729.}

임은주, 권미선, 심현섭(2001). 경중도에 따른 유창성 실어증 환자의 정보전달능력에 관한 연구. 언어청각장애연구, 6(2), 374-391.

진천, 최현주, 이준영(2016). 경도인지장애 및 알츠하이머형 치매 환자의 자발화 분석 척도의 유용성. Communication Sciences \& Disorders, 21(2), 284-294.

최현주(2015). 일반 노인의 정보 전달 능력과 인지기능과의 상관. Communication Sciences \& Disorders, 20(3), 435-445.

편성범(2008). 한국판 프렌차이 실어증 선별검사(Korean-Frenchay Aphasia Screening Test, K-FAST). 서울: 한미.

한우주, 임동선(2016). 단순언어장애 아동의 구문점화 방식에 따른 복문 산출 능력과 암묵적 학습 및 작업기억 간의 관계. Communication Sciences

\& Disorders, 21(4), 590-604.

황윤미, 박현린, 김승희(2019). 언어재활사의 언어학습장애 치료에 관한 질적 연구: 읽기 및 쓰기 중재에서 경험하는 어려움을 어떻게 해결하는가?

Communication Sciences \& Disorders, 24(2), 416-431.

\section{ORCID}

윤지혜(제1저자, 교수 https://orcid.org/0000-0003-1403-2276); 오소정(공동저자, 교수 https://orcid.org/0000-0002-1427-5828);

이윤경(교신저자, 교수 https://orcid.org/0000-0002-9759-6247) 